\title{
Takings: Physical and Regulatory
}

\author{
David L Callies*
}

\section{Introduction}

The withdrawal of Hong Kong from the British Commonwealth and its resulting status as an administrative region of The People's Republic of China has changed several aspects of fundamental law in Hong Kong. One such aspect is the effect on the law of real property. ${ }^{1}$ Courts in Hong Kong have begun to cite US case law for various propositions of law, and particularly in the area of compensation for land use regulations that affect otherwise permitted uses of land. In the United States, regulations that go 'too far' may be considered takings, for which compensation from the government regulator may be due. In other words, under certain circumstances, the effect of a regulation is deemed similar to an exercise of the

David Callies is the Kudo Professor of Law, William S Richardson Law School, University of Hawaii and an elected member of the College of Fellows, American Institute of Certified Planners; American College of Real Estate Lawyers; and the American Law Institute. He holds the following degrees and honors: $\mathrm{AB}$, Depauw University; JD, University of Michigan; LLM, Nottingham University; Life Member, Clare Hall, Cambridge. He is past chair of: Academics Forum, International Bar Association; Section of State and Local Government Law, American Bar Association; Section of State and Local Government Law, American Association of Law Schools; and Section of Real Property and Financial Services, Hawaii State Bar Association. He is national co-editor (with Tarlock), of the Land Use and Environmental Law Review. The author acknowledges with thanks the research assistance of Tina Wakayama, Comments Editor, University of Hawaii Law Review.

1 See, eg, Anton Cooray, 'Government as Ground Landlord and Land Use Regulator: The Hong Kong Experience', in Tsuyoshi Kotaka and David L Callies (eds), Taking Land: Compulsory Purchase and Regulation in Asian-Pacific Countries (Hawaii: University of Hawaii Press, 2002). The latter was republished in early 2007 in a Japanese translation by Associate Professor Masaki Igawa of the Meijo University (Nagoya) Faculty of Law. 
power to compulsory purchase land, which in the US is regarded as an exercise of the power of eminent domain. ${ }^{2}$

In particular, the High Court of the Hong Kong Special Administrative Region has cited US authority and made arguments using language suggesting the use of US precedent in regulatory takings in its recent decision in Fine Tower Associates, LTD $v$ Town Planning Board, decided in April of $2005 .{ }^{3}$ There, the occupant of land under the typical Hong Kong long term ground lease challenged the application of an Outline Zoning Plan (hereafter OZP) to the subject property on the ground that the limitations thus imposed on use amounted to a deprivation of the applicant's rights in land, demanding either an amendment to the draft OZP or a recommendation that the land be 'resumed' (the rough equivalent of a compulsory taking) and compensation paid, as required by Articles 105 and 6 of the Basic Law governing Hong Kong. ${ }^{4}$ The Department of Justice took the position that the argument that the draft OZP was tantamount to compulsory acquisition of land was untenable.

In holding that the draft OZP did not 'take' property rights protected by the Basic Law, the Court first quoted extensively from an earlier case which cited US regulatory takings cases upholding land use regulations against takings challenges: Grape Bay Limited v Attorney General of Bermuda. ${ }^{5}$ There, the Privy Council held it was 'well settled' that restrictions on the use of property imposed in the public interest by general regulatory laws do not constitute a deprivation of property for which compensation should be paid, citing the unsuccessful facial challenges to zoning regulations in Village of Euclid $v$ Ambler Realty $\mathrm{Co}^{6}{ }^{6}$ and Penn Central Transportation Co v New York City. ${ }^{7}$ However, the Court also cited the more recent Hong Kong case of Kowloon Poultry Loan Merchants Association v Director of Agricultural Fisheries and Conservation, ${ }^{8}$ in which the court stated that deprivation of property is not limited to cases where property is formally expropriated, but may also exist where a regulation so affects the 'substance' of the property that there has been a de facto expropriation. Citing the seminal US case on regulatory takings, Pennsylvania Coal Co v Mahon, ${ }^{9}$ the Court then noted that if a measure restricting the use and enjoyment of property goes too far, that will be recognized

2 See, eg, Steven J Eagle, Regulatory Takings (Lexis, 2d ed 2001); Robert Meltz, Dwight H Merriam \& Richard M Frank, The Takings Issue: Constitutional Limits on Land Use Control and Environmental Regulation (Washington, DC: Island Press, 1999); Fred Bosselman, David L Callies \& John Banta, The Taking Issue (Washington: US Government Printing Office, 1973).

[2005] HKCU 504, (CFI) (Unreported).

Ibid, paras 22-23.

[1999] 1 WLR 574 (PC).

272 US 365 (1926).

438 US 104 (1978).

[2002] 4 HKC 277, (CA).

260 US 393 (1922). 
as a taking, requiring compensation. Holding that such a conclusion was for the Town Planning Board to reach, and that there was a viable argument that the draft OZP could constitute such a deprivation by regulation, the Court remanded to the Board to hear full argument. The Board reconsidered the matter and concluded that its decision would not amount to a deprivation of property, a decision which was upheld by the Court of First Instance. ${ }^{10}$

While the above briefest of summaries of some of the relevant cases may not be sufficient to fully set out the present state of physical and regulatory takings law in Hong Kong, it is perhaps enough to demonstrate increasing citation of, if not reliance upon, US takings jurisprudence in this field. It therefore becomes more than simply a useful exercise to sketch the basics of that law in the United States together with selected examples of what inferior (lower) federal and state courts in the United States have done with that jurisprudence. What follows is a summary of the pertinent US cases, in the context of the current state of physical and regular takings jurisprudence in the United States, together with selected examples from 'lower' courts. "We commence with the US law on physical takings or compulsory purchase, to which the law of taking by regulation directly relates.

\section{Physical Takings: Eminent Domain in the United States}

Generally, any unit of government in the United States-federal, state or localcan use its sovereign powers to take private land for public use. The same is true for quasi-governmental agencies and public corporations and utilities. The limits placed on the exercise of that power are defined in the statutes that created them. ${ }^{12}$ The technical term most often used, 'eminent domain,' does not imply that a government's right to take such real estate interests is based on a preeminent sovereign title or prerogative. ${ }^{13}$ Rather, most authorities agree it is based on the concept that the power is necessary to fulfill a sovereign governmental function, in the interests of all the people which that government, as a general purpose

10 Fine Tower Associates, LTD v Town Planning Board [2006] 4 HKLRD 34 (CFI).

11 See, for further analysis and background, Steven J Eagle, Regulatory Takings (Lexis, 2d ed 2001); Robert Meltz, Dwight H Merriam \& Richard M Frank, The Takings Issue: Constitutional Limits on Land Use Control and Environmental Regulation (Washington, DC: Island Press, 1999); Fred Bosselman, David L Callies \& John Banta, The Taking Issue (Washington: US Government Printing Office, 1973).

12 Dankert, 'Planning for Condemnation-the Condemnor's Problems', in Institute on Planning, Zoning and Eminent Domain , (Matthew Bender, 1989) at s 11. 03. See Albert Hanson Lumber Co v US, 261 US 581, 587 (1923) and US $v$ Carmack, 329 US 230, 241242 (1946).

13 See Gavin M Erasmus, Eminent Domain Jurisprudence, 1-2 (ALI-ABA Course of Study, 7 January 1993). 
government, represents. ${ }^{14}$ The power is thus based not on ultimate ownership by the state, but on the exercise of its sovereign powers, vested in the legislature but exercised by the executive branch of government. ${ }^{15}$

However, to say that eminent domain is a fundamental attribute of sovereignty clashes with the concept of individual rights, particularly those to private property: if government may take property for a public use, then the individual has no guarantee that private property is safe from confiscation. Indeed, there is no such guarantee under the British system of government. The American solution to the dilemma was to adopt such a guarantee of private property rights in the Fifth Amendment to the United States Constitution, which provides that government shall not take private property except for a public use and upon payment of just compensation. ${ }^{16}$ Thus, the US Constitution limits the exercise of eminent domain by the federal government (public use and compensation) which is presumed to have such power (though never expressly granted) which limitation is extended to the states by the Federal Constitution's 14 th Amendment.

The power to initiate the exercise of eminent domain ordinarily resides exclusively in the legislature. In some cases the legislature itself, by mere enactment of a statute or resolution, affects the taking of certain land or interest in land for public use. In cases where a constitutional provision is self executing and declares that land can be condemned for certain specified uses, proceedings to take land for such purposes may be instituted without waiting for authority from the legislature. For example, municipal corporations have no prerogative right to exercise the power of eminent domain and cannot take land for public uses unless the power has been conferred on them by the legislature. However, there have been cases where a state constitution authorizes cities to write their own charters. In such instances, a city may give itself the power of eminent domain and provide that it may exercise the power beyond its own limits, without the aid of any legislative act. ${ }^{17}$

Both private and public corporations have the right to take property if that right is delegated to them by the state. Legislatures can create different classes of corporations that are authorized to use eminent domain. ${ }^{18}$ Government imposes different burdens in the exercise of eminent domain under the same conditions for municipal corporations and private corporations because there is sufficient difference between them. ${ }^{19}$

\section{A. The Public Use Requirement}

While the definition of public use has not changed significantly in the past twenty years, public perception of that change has. The federal rule, anticipated in Berman

14 West River Bridge Co v Dix, 47 US 507 (1848).

15 29A CJS Eminent Domain $\$ 2$ (2007).

16 US Const The Fifth Amendment.

17 1A Nichols on Eminent Domain $\$ 3.03[1]$.

18 1A Nichols on Eminent Domain $\$ 3.04[2]$.

19 Ibid; Steinhart v Mendocino County Ct, 70 P 629 (Cal 1902). 
$v$ Parker ${ }^{20}$, was established in Hawaii Housing Authority ('HHA') v Midkiff: ${ }^{21}$ so long as a public use (redefined as public purpose) is conceivable and possible, even if it never comes to pass, federal courts will accept it. The US Supreme Court simply reiterated that rule in the 2005 case of Kelo v New London, ${ }^{22}$ holding that economic revitalization was a sufficient public purpose to justify the taking of a non-blighted single family home under local eminent domain statutes. A number of state courts had established a more stringent test than the supreme court of Connecticut, (which the Court affirmed in Kelo), which, of course, the states may do since further protecting property rights beyond the minimum under federal law is a matter for the states, as indeed the Supreme Court noted in Kelo. Nevertheless, the decision set off a firestorm of criticism, leading to pending legislation in two-thirds of the states to establish a more strict public purpose test to avoid results such as that in Kelo.

In Kelov City of New London, ${ }^{23}$ a bare majority of the Court upheld the exercise of eminent domain for the purpose of economic revitalization. Heavily relying on its previous decisions in Berman v Parker, ${ }^{24}$ and HHA v Midkiff, ${ }^{25}$ the Court stated that it was too late to revisit its present expansive view of public use, formally stating that there is no difference in modern eminent domain practice between public use and public ${ }^{26}$ purpose-at least in federal court. Indeed, by a narrow $5 / 4$ vote, the Court specifically equated public use and public purpose before holding that condemning land for economic revitalization was at worst simply another small step along the continuum of permitting public benefits to be sufficient indicia of meeting public use/public purpose requirements for purposes of the Fifth Amendment's Takings Clause. ${ }^{27}$ As the Court also noted, it is now up to the states to decide whether or not to increase the burden on government exercise of compulsory purchase powers. ${ }^{28}$

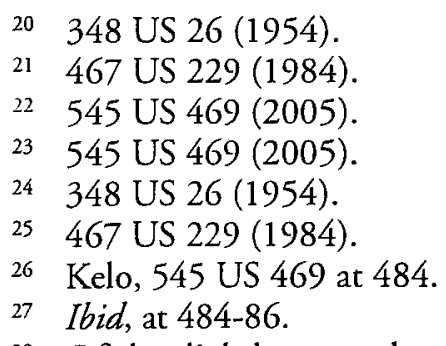

28 Of the slightly more than a dozen state courts that have considered whether economic revitalization is sufficient public use for governmental exercise of eminent domain, about half have decided-like Connecticut-that it is. Now the US Supreme Court has decided that it is.About half-like Michigan in its recent and thoroughly reviewed and discussed County of Wayne v Hathcock, 684 NW2d 765 (Mich 2004) - have decided that it is not, utilizing various tests such as whether the condemnation serves primarily a public purpose or primarily benefits the private sector. See, for extensive analysis and commentary, Amanda Eckhoff and Dwight A Merriam, 'Public Use Goes Peripatetic: First, Michigan Reverses Poletown and Now the Supreme Court Grants Review in an Eminent Domain Case' (Jan 2005) 56 Plan \& Envtl L No 1; Steven J Eagle, 'The Public Use Requirement and Doctrinal Renewal' (2004) 34 Envtl L Rep 10999. 


\section{The State of the Federal Law on Public Use Before Kelo: Berman $v$ Parker and HHA $v$ Midkiff}

In Berman the Court dealt with the condemnation of a thriving department store contained in a large parcel condemned by a redevelopment agency for the statutory (Congressional in this instance) purpose of eliminating blight, all in accordance with a required redevelopment plan. ${ }^{29}$ Justice Douglas for the majority commenced by observing famously that a community could decide to be attractive as well as safe, and that in thus justifying eminent domain to accomplish these goals, "We deal, in other words ... with the police power. ${ }^{30}$ This led to a controversial joining of the two powers which has affected definitions of public use ever since by obviating any need for the public to actually use the property condemned so long as it furthered a public purpose. Indeed, the landowners pointed out that their land would simply be turned over to another private owner. ${ }^{31}$ No matter, said Douglas: 'But the means of executing the project are for Congress and Congress along to determine, once the public purpose has been established. The public end may be as well or better served through an agency of private enterprise than through a department of government-or so the Congress might conclude. We cannot say that public ownership is the sole method of promoting the public purposes of community redevelopment projects'. ${ }^{32}$

To the landowners' argument that their particular parcel was unblighted and that therefore its condemnation violated the Fifth Amendment's public use clause, Justice Douglas responded that if experts concluded the area must be planned as a whole in order to prevent reversion to a slum, so be it. ${ }^{33}$ Despite this broad language, many conceived the decision to apply largely to redevelopment projects, and in particular those which were well-planned in accordance with clear statutory mandates. Not so after HHA v Midkiff.

In 1967 the Hawaii State Legislature passed a land reform act the principal purpose of which was to eliminate a perceived oligopoly in available residential land which was thought to adversely affect the price and availability of housing for its citizens. ${ }^{34}$ Eminent domain was the means chosen to solve the problem. The act authorized a state agency - the Hawaii Housing Authority-to condemn the fee simple interest in land which was leased to individual homeowners, for the purpose of conveying that interest to some other private owner, usually the existing owner's lessee who owned the house on the land. ${ }^{35}$ The main target of the legislation was the Bishop Estate (as it was then known), a charitable trust created by Princess

\footnotetext{
Berman, 348 US 26 at 31.

Ibid, at 32.

Ibid, at 31 .

Ibid, at 33-34.

Ibid, at 34-35 (citations omitted).

Midkiff, 467 US 229 at 232-33.

Ibid, at 233.
} 
Bernice Pauahi Bishop, a descendent of King Kamehameha the Great and whose large landholdings she eventually inherited. The Estate challenged the act's condemnation process as a taking without the public use required by the US Constitution's Fifth Amendment. ${ }^{36}$ While the Federal District Court upheld the statute, the Ninth Circuit Court of Appeals held that the statute essentially provided for a 'naked' transfer from one private individual to another, and so lacked the requisite public use. ${ }^{37}$

In a unanimous decision, the US Supreme Court reversed the Ninth Circuit. Citing Berman, the court explained that courts should not interfere once a legislative body has declared a public purpose, unless that purpose was 'palpably without reasonable foundation' or involved an 'impossibility. 38 The means were irrelevant; this was simply a mechanism or process to accomplish the legislatively-declared public purpose. Indeed, it would make no difference, said Justice O'Connor writing for the Court, if that public purpose never came to pass, so long as the legislature could reasonably have thought it would when enacting the statute. ${ }^{39}$ Note throughout the frequent use of public purpose, instead of public use. These words would come back to haunt Justice O'Connor in Kelo.

\section{Kelo $v$ City of New London: Midkiff and Berman Followed}

The Court in Kelo simply extended the reasoning in Berman and Midkiff to the economic revitalization condemnations that are increasingly common throughout urban areas in the United States. Indeed, the majority was singularly unimpressed with extreme uses of eminent domain for the purposes of providing employment and bettering the local tax base which the parties brought to its attention: 'A parade of horribles is especially unpersuasive in this context since the Takings Clause largely operates as a conditional limitation permitting the government to do what it wants so long as it pays the charge. ${ }^{.40}$

The facts in Kelo are straightforward. In order to take advantage of a substantial private investment in new facilities by Pfizer, Inc, in an economically depressed area of New London, Connecticut, the City reactivated the private non-profit New London Development Corporation (NLDC) to assist in planning the area's economic development. Authorized and aided by grants totaling millions of dollars, NLDC held meetings and eventually 'finalized an integrated development plan focused on 90 acres.' The NLDC successfully negotiated the purchase of most of the real estate in the 90 -acre area, but its negotiations with the owners of 15

Ibid, at 234-35.

Ibid, at 235.

Ibid, at 240-42.

Ibid, at 241 .

40 Kelo, 445 US 469, at 487, n19 (citing Eastern Enterprises v Apfel, 524 US 498, 545 (1998)). For a compendious list of such 'horribles,' see Dana Berliner, Public Power, Private Gain (2003), available at http://www.castlecoalition.org/publications/report/index.html. 
properties failed. When the NLDC initiated condemnation proceedings the landowners sued. Among them was Susette Kelo, who had lived in the Fort Trumbull redevelopment area since 1997. Kelo had made extensive improvements to her house, which she prized for its water view. Another petitioner, Wilhelmina Dery, was born in her Fort Trumbull house in 1918 and lived there her entire life. Although there was no allegation that any of these properties were blighted or otherwise in poor condition, they were nevertheless condemned with the others 'because they happen to be located in the development area. ${ }^{41}$ On these facts, petitioners claimed that the taking of their property violated the public use clause of the Fifth Amendment.

The trial court granted a permanent restraining order prohibiting the taking of some properties but not others, and both sides appealed to the Supreme Court of Connecticut. That court held that all of the City's proposed takings were constitutional. Noting that the proposed takings were authorized by the state's municipal development statute and in particular the taking of even developed land as part of an economic development project was for a public use and in the public interest, the court relied on Berman and Midkiff in holding that such economic development qualified as a public use under both federal and state constitutions. The US Supreme Court granted certiorari 'to determine whether a city's decision to take property for the purpose of economic development satisfies the "public use" requirement of the Fifth Amendment.' 42

The Court's answer: an unequivocal yes. While the Court noted that the sovereign may not take the property of $A$ for the sole purpose of transferring to another private party $B \ldots$ it is equally clear that a State may transfer property from one private party to another if future 'use by the public' is the purpose of the taking. ${ }^{33}$ The issue, then, is what constitutes sufficient use by the public. Three factors appear to be important in reaching the conclusion that economic revitalization in New London constitutes such use: a rigorous planning process, the Court's precedents embodied in Berman and Midkiff, and deference to federalism and state decision making.

The Court commenced its analysis by reiterating that private-private transfers alone are unconstitutional and any pretextual public purposes meant solely to accomplish such transfers would fail the public use test. However, the Court observed that the governmental taking in Kelo was meant to 'revitalize the local economy by creating temporary and permanent jobs, generating a significant increase in tax revenue, encouraging spin-off activities and maximizing public access to the waterfront ${ }^{\text {'44 }}$ all in accordance with a 'carefully considered' ${ }^{45}$ and 'carefully

\footnotetext{
$41 \quad$ Ibid.

42 Ibid, at 477 . A petition for a writ of certiorari is the method for seeking review of lower court decisions by the US Supreme Court.

43 Ibid.

44 Ibid.

45 Ibid, at 478 .
} 
formulated' 46 development plan in accordance with a state statute 'that specifically authorizes the use of eminent domain to promote economic development." 47 Therefore, the 'record clearly demonstrates that the development plan was not intended to serve the interests of Pfizer, Inc, or any other private entiry. ${ }^{38}$ Indeed, the Court was particularly impressed by 'the comprehensive character of the plan [and] the thorough deliberation that preceded its adoption. ${ }^{39}$ Although little in the plan demonstrated any actual use by the public, the Court observed that it had embraced a broader and more 'natural' interpretation of public use as public purpose at least since the end of the 19th Century and 'we have repeatedly and consistently rejected that narrow [use by the public] test ever since. ${ }^{50}$

Next, the Court observed that this broad definition of public use accorded with its 'longstanding policy of deference to legislative judgments in this field.' 51 The Court then discussed its decisions in Berman and Midkiff as demonstrations of such legislative deference, quoting heavily from the language in Berman about 'the power of the legislature to determine that the community should be beautiful as well as healthy, spacious as well as clean, well-balanced as well as carefully patrolled. ${ }^{52}$ The Court concluded that its 'jurisprudence has wisely eschewed rigid formulas and intrusive scrutiny in favor of affording legislatures broad latitude in determining what public needs justify the use of the takings power. ${ }^{53}$

The Court steadfastly rejected any suggestion that it formulate a more rigorous test. ${ }^{54}$ Thus, for example, to require government to show that public benefits would actually accrue with reasonable certainty or that the implementation of a development plan would actually occur would take the Court into factual inquiries already rejected in an earlier regulatory takings case. ${ }^{55}$ Similarly, the Court declined to second-guess the city's determinations as to what lands it needed to acquire in order to pursue the project. ${ }^{56}$ Lastly, the Court rejected the invitation by some amici (friend of the court briefs) to deal with the appropriateness of compensation under the circumstances. While the Court acknowledged the hardships which the condemnations might entail in this case, these questions are not before us in this litigation' even though members of the Court itself raised the adequacy of

$46 \quad$ Ibid, at 483 .

47 Ibid, at 484 .

$48 I b i d$, at $478, \mathrm{n} 6$.

49 Ibid, at 484 .

so Ibid, at 480.

51 Ibid.

52 Ibid. (quoting Berman v Parker, 348 US 26, 33 (1954)).

53 Ibid, at 483.

54 Ibid, at 487.

55 Lingle $v$ Chevron USA Inc, 544 US 528 (2005).

56 Kelo, 454 US 469, 488-89. 
compensation during oral argument. ${ }^{57}$ In a nod to federalism and states rights, the Court closed by leaving to the states any remedy for such hardships posed by the condemnations in New Canaan: 'We emphasize that nothing in our opinion precludes any State from placing further restrictions on its exercise of the takings power. Indeed, many states already impose "public use" requirements that are stricter than the federal baseline. ${ }^{.58}$

Only Justice Kennedy's concurrence suggests some small role yet for federal courts in determining that a particular exercise of eminent domain might fall short of the required public use requirement: 'There may be private transfers in which the risk of undetected impermissible favoritism of private parties is so acute that a presumption (rebuttable or otherwise) of invalidity is warranted under the Public Use Clause. ${ }^{59}$ This is, however, largely a due process argument rather than a Fifth Amendment argument, and in any event, continued Kennedy: 'This demanding level of scrutiny is not required simply because the purpose of the taking is economic development. ${ }^{\prime 60}$

\section{The Dissents: What's Wrong with Kelo (and Midkiff and Berman)?}

The argument for a judicial hands-off is not so strong as the Court majority suggests, however, as the vigorous dissents from Justices O'Connor and Thomas demonstrate. Particularly strong is the dissent by Justice O'Connor who wrote the broadlyworded Midkiff opinion for a unanimous Court in 1984. Observing that the question of what is a public use is a judicial, not a legislative one, ${ }^{61}$ Justice O'Connor commences by declaring that if economic development takings meet the public use requirement, there is no longer any distinction between private and public use of property, the effect of which is "to delete the words "for public use" from the Takings Clause of the Fifth Amendment. ${ }^{62}$

But what then of Berman and her own language in Midkiff? These decisions, according to O'Connor, were exceptions to the Court's jurisprudence which required public use to be actual use by the public. The Court, says O'Connor, has

57 Ibid, at 489, n 21 Other countries provide a measure of extra compensation where, as here, it is a private residence which is condemned and the landowner has a demonstrable emotional attachment to the improved land. See, eg, the Australian concept of solatium, amounting to up to $10 \%$ additional compensation beyond fair market value in such circumstances, briefly noted (among other compensation issues) in Lee Anne Fennell, 'The Death of Poletown: The Future of Eminent Domain and Urban Development After County of Wayne v Hathcock: Taking Eminent Domain Apart' (2004) 2004 Mich St L Rev 957, 1004 (referencing Murray $\mathrm{J}$ Raff, 'Planning Law and Compulsory Acquisition in Australia', in Tsuyoshi Kotaka \& David L Callies (eds), Taking Land: Compulsory Purchase and Land Use Regulation in Asian-Pacific Countries (Hawaii: University of Hawaii Press, 2002), pp 27, 44. Kelo, 454 US 469, 489.

59 Ibid, at 493 (Kennedy, J, concurring) (emphasis in original).

60 Ibid.

${ }^{61}$ Ibid, at 499 (O'Connor, J, dissenting) (citing Cincinnati v Vester, 281 US 439 (1930)).

62 Ibid, at 494 . 
'identified' three categories of public use takings of private property:

1. transfers to public ownership for such as roads, hospitals and military bases; ${ }^{63}$

2. transfers to private common carriers or utilities for railroads or stadia (both of which she characterizes as 'straightforward and uncontroversial') ${ }^{64}$ and;

3. the rare 'public purpose' case 'in certain circumstances and to meet certain exigencies' ${ }^{35}$ such as the eradication of blight and slums in Berman and the elimination of oligopoly in Midkiff, where deference to legislative determinations were warranted because the 'extraordinary precondemnation use of the targeted property inflicted affirmative harm on society. ${ }^{36}$

In other words, these were exceptional circumstances clearly not replicated in New London, and the application of this third exceptional category in these circumstances significantly expands the meaning of public use. ${ }^{67}$ If, as the majority suggests, government can take private property and give it to new private users so long as the new use is predicted to generate some secondary public benefit like increased tax revenues or more jobs, then 'for public use' does not exclude any takings. ${ }^{68}$

Dismissing Justice Kennedy's test as one which no one but a 'stupid staffer' 69 could fail, Justice O'Connor finds the logic of the Court's decision such that '[n] othing is to prevent the State from replacing any Motel 6 with a Ritz-Carlton, any home with a shopping mall, or any farm with a factory. ${ }^{70}$ Leaving any tougher standards designed to limit such possibilities to the states is an abdication of our responsibility. States play many important functions in our system of dual sovereignty, but compensating for our refusal to enforce properly the Federal Constitution ... is not among them. ${ }^{.71}$ She ends with concerns for those with fewer resources who will suffer in contests over exercises of eminent domain with those with 'disproportionate influence and power in the political process, including large corporations and development firms[.] ${ }^{72}$

Justice Thomas raises similar concerns in his dissent, but in considerably more detail. Picking up on Justice O'Connor's concern for the politically least powerful

63 Ibid, at 497.

64 Ibid.

65 Ibid, at 498.

66 Ibid, at 500 .

67 Ibid, at 501 .

68 Ibid, Justice O'Connor also confesses error (her own as well as the Court's) in ever equating public use and the police power, from which, she accurately observes, much of the expanded doctrine of public use into broad public purpose, and particularly deference to legislative determinations of public purpose, derive.

$69 \quad$ Ibid, at 502.

$70 \quad$ Ibid, at 503.

71 Ibid, at 504.

72 Ibid, at 505 . 
and characterizing the Court's deferential standard as 'deeply perverse,' Justice Thomas provides several examples indicating that those uprooted in even the urban renewal cases were overwhelmingly poor, elderly, black, or all of the above. ${ }^{73}$ His disagreement with the Court, however, goes much deeper than that of Justice O'Connor. Reviewing a series of court opinions and writings from the late 18th Century, Justice Thomas concludes that the cases cited by the majority for the proposition that public use meant public purpose rather than use by the public in the early years of the republic were exceptions-aberrations that varied from the usual rule. Thomas concludes that the Court's current public use jurisprudence therefore rejects the original meaning of the public use clause, to which he urges the Court to return, and from which it has clearly deviated. ${ }^{74}$

\section{The Backlash}

a. The States Rebel: Statutory and Constitutional Provisions Enacted to Limit Eminent Domain Power in the Wake of Kelo

More than a year after the United State's Supreme Court's decision in Kelo, the public concern regarding eminent domain abuse continues unabated. ${ }^{75}$ Legislators in 47 states have introduced, considered or passed legislation limiting the government's eminent domain powers in instances of private use since the Court's unpopular decision in June of $2005 .^{76}$ Thirty states, out of the forty-five that were in session, enacted legislation aimed at curbing eminent domain abuse. ${ }^{77}$ Of these

73 Ibid, at 522 (Thomas, J, dissenting).

74 Ibid, at 523 .

75 Grass roots groups such as the Institute for Justice and its property rights counterpart, the Castle Coalition, have been tracking and encouraging policy movements at the State and local level. See www.castlecoalition.com and www.ij.org, for more information on these groups.

76 Lisa Knepper and John Kramer, 'Iowa Legislature Overrides Eminent Domain Reform Veto: Historic Event Secures Greater Property Protection', 14 July 2006, http://www. castlecoalition.org/media/releases/7_14_06pr.html.

77 Alabama (2005 AL SB 68A), Alaska (2005 AK HB 319), Colorado (2006 CO HB 1411), Delaware (2005 DE SB 217), Florida (2006 FL HB 1567, 2006 FL HB 1569, 2006 FL V 8), Georgia (2005 GA HB 1313, 2005 GA HB 1306), Idaho (2006 IBID SB 1243, 2006 IBID SB 1247, 2006 IBID HB 555), Indiana (2006 IN HB 1010), Illinois (2005 IL SB 3086), Iowa (2005 IA HB 2351), Kansas (2005 KS SB 323), Kentucky (2006 KY HB 508), Louisiana (2006 LA SB 1, 2006 LA SB 43A, 2006 LA HB 707), Maine (2005 ME HB 1310), Michigan (2005 MI SJR E), Minnesota (2005 MN SB 2750), Missouri (2006 MO HB 1944), Nebraska (2005 NE LB 924), New Hampshire (2005 NH SB 287), North Carolina (2006 NC HB 1965), Ohio (2005 OH SB 1667), Pennsylvania (2005 PA HB 2054, 2005 PA SB 881), South Carolina (2006 SC SB 1031), South Dakota (2006 SD HB 1080), Tennessee (2005 TN HB 3450), Texas (2005 TX SB 7B), Utah (2006 UT SB 117), Vermont (2005 VT SB 246), West Virginia (2006 WV HB 4048), Wisconsin (2005 WI AB 657). Information taken from Castle Coalition, Legislative Action Since Kelo, available at http://www.castlecoalition.org/pdf/publications/State-Summary-Publication.pdf (last visited at 7 October 2006). 
thirty states, twenty-seven governors have signed reform legislation into law. ${ }^{78}$ Iowa, Arizona and New Mexico are the only states whose governors vetoed eminent domain reform, and Iowa is the first to override such a veto. ${ }^{79}$ Local governments are also taking measures to protect their homeowners, with more than 70 cities and counties introducing their own bills to restrict the use of eminent domain. ${ }^{80}$

Citizens in Arizona, California, Idaho, Florida, Georgia, Oregon Louisiana, Michigan, Nevada, New Hampshire, North Dakota and South Carolina voted on ballot measures directed at curbing eminent domain abuse. Montana, which was previously scheduled to vote on two constitutional initiatives aimed at private property rights and limiting the purposes for which the government may take private property respectively, did not vote on the ballot measures because they were both withdrawn by their sponsors. ${ }^{81}$ After the election the number of states that have limited eminent domain has risen from 30 to $34 .^{82}$

\section{b. United States Congress Gets Into the Act}

Although both the US House of Representatives and the US Senate have introduced numerous bills attempting to restrict eminent domain abuse since the Supreme Court decided Kelo, HR 3058 is the only one to survive. ${ }^{83}$ The bill, which became law on November 30,2005, ${ }^{84}$ provides that 'no funds in this Act may be used to support any Federal, State, or local projects that seek to use the power of eminent domain, unless eminent domain is employed only for a public use.' The bill further specifically states that 'public use shall not be construed to include economic development that primarily benefits private entities.' In addition, the bill provides that the Government Accounting Office conduct a study on the nationwide use of eminent domain, including the procedures used and the results accomplished on a state-by-state basis as well as the impact on individual property owners and on the affected communities. ${ }^{85}$ The study, which was supposed to be submitted to Congress within 12 months of the enactment of the Act, has yet to be submitted. Obviously, 30 September 2006 has come and gone. HR 5576, an appropriations bill for

78 See Knepper and Kramer, 'Iowa Legislature Overrides Eminent Domain Reform Veto: Historic Event Secures Greater Property Protection' (note 88 above).

79 Ibid.

80 See Castle Coalition's Legislative Center, available at http://www.castlecoalition.org/ legislation/local/index.asp (last visited at 17 October 2006).

81 See http://sos.mt.gov/ELB/archives/2006/Ballot_Issues.asp. (last visited on 12 November 2006).

82 John Kramer and Lisa Knepper, '2006 Election Wrap Up: Voters Overwhelmingly Passed Eminent Domain Reform', 8 November 2006, available at http://www.castlecoalition.com/ media/releases/11_8_06pr.html.

83 See Castle Coalition, Legislative Center: Current Proposed Federal Legislation On Eminent Domain, available at http://www.castlecoalition.org/legislation/federal/index.html (last visited on 17 October 2006 ).

${ }_{84}$ Ibid; HR 3058, 109th Cong (2005) (enacted).

85 HR 3058, 109th Cong $\$ 726$ (2005) (enacted). 
Fiscal Year 2007, is currently being debated. ${ }^{86}$ If enacted as presently written, it will keep the restrictions in HR 3058 in place.

Other bills are more sharply critical of eminent domain abuse, such as the Private Property Protection Act of 2005. That Act, also known as HR 4128, provides that: 'No State or political subdivision of a State shall exercise its power of eminent domain, or allow the exercise of such power by any person or entity to which such power has been delegated, over property to be used for economic development or over property that is subsequently used for economic development, if that State or political subdivision receives Federal economic development funds during any fiscal year in which it does so'. It also prohibits the federal government from condemning property for economic development ${ }^{87}$ The bill passed the House on November 3, 2005 but it has languished in the Senate Judiciary Committee ever since. ${ }^{88}$

\section{c. Recent Court Decisions After Kelo}

i. Board of County Commissioners of Muskogee County v Lowery

In one of the first state supreme court decisions issued after Kelo, the Oklahoma Supreme Court held that 'economic development alone does not constitute a public purpose[.] ${ }^{89}$ In that case, Muskogee County brought condemnation proceedings against landowners for the purpose of acquiring right-of-way easements for the placement of three water pipelines, two of which would solely service Energetix, LLC, a private electric generation plant proposed for construction and operation in the County. The landowners objected to the proceedings 'primarily on the basis that the takings were not for a valid public purpose, but rather an unlawful taking of private property for private purpose. ${ }^{.90}$ The trial court sided with the County but the appellate court reversed, holding that the takings were unlawful because they were for the 'direct benefit of a private company' and not for 'public purposes. ${ }^{91}$ The County appealed.

Agreeing with the appellate court, the Oklahoma Supreme Court reasoned: 'We adhere to the strict construction of eminent domain statutes in keeping with our precedent, mindful of the critical importance of the protection of individual private property rights as recognized by the framers of both the US Constitution and the Oklahoma Constitution. If we were to construe "public purpose" so broadly as to include economic development within those terms, then we would effectively

86 Castle Coalition, Legislative Action Since Kelo, available at http://www.castlecoalition. org/pdf/publications/State-Summary-Publication.pdf (last visited at 7 October 2006).

87 See Castle Coalition, Legislative Center: Current Proposed Federal Legislation On Eminent Domain (note 95 above).

88 Lisa Knepper and John Kramer, 'US Senate Eminent Domain Reform Deadline Tomorrow Time is Running Out For Federal Government to Stop Funding Abuse', 29 September 2006, http://www.castlecoalition.org/media/releases/9_29_06pr.html.

89 Board of County Comm'rs of Muskogee County v Lowery, 136 P3d 639, 650 (2006).

90 Ibid, at 644.

91 Ibid, at 645 . 
abandon a basic limitation on government power by "wash[ing] out any distinction between private and public use of property-and thereby effectively delet [ing] the words 'for public use' from [the constitutional provisions limiting governmental power of eminent domain.]"'92

The court specifically distinguished this case from Kelo: 'Contrary to the Connecticut statute applicable in Kelo, which expressly authorized eminent domain for the purpose of economic development, we note the absence of such express Oklahoma statutory authority for the exercise of eminent domain in furtherance of economic development in the absence of blight'..$^{3}$

The court explained that its decision was 'reached on the basis of Oklahoma's own special constitutional eminent domain provisions[.]' ${ }^{94}$ The court observed that while the Takings Clause of the US Constitution provides 'nor shall private property be taken for public use without just compensation,' the Oklahoma Constitution places further restrictions by expressly stating that 'no private property shall be taken or damaged for private use, with or without compensation. ${ }^{\prime 9}$ The Court held that although the Oklahoma constitution expressly lists exceptions for common law easements by necessity and drains for agricultural, mining and sanitary purposes, the proposed purpose of economic development did not fall within any of these categories: ${ }^{66}$ "To permit the inclusion of economic development alone in the category of "public use" or "public purpose" would blur the line between "public" and "private" so as to render our constitutional limitations on the power of eminent domain a nullity. If property ownership in Oklahoma is to remain what the framers of our Constitution intended it to be, this we must not do..$^{97}$ Accordingly, the court held that 'economic development alone does not constitute a public purpose and therefore, does not constitutionally justify the County's exercise of eminent domain. ${ }^{98}$

\section{ii. Burien v Strobel Family Investments}

The Court of Appeals of Washington affirmed a trial court decision holding that the City's exercise of eminent domain to condemn a restaurant for a new 'Town Square' development was not arbitrary or capricious. ${ }^{99}$ The decision makes no mention of Kelo or the recent public use versus public purpose debate. The court simply applied Washington's three-part test in evaluating eminent domain: 'For a proposed condemnation to be lawful, the condemning authority must prove that

Ibid, at 647. (quotations and brackets in original) (citing Kelo, 545 US 469, (2005) (O'Connor, J, dissenting)).

Ibid, at 650.

Ibid, at 651 .

Ibid, at 652.

Ibid.

Ibid.

Ibid, at 650 .

Burien $v$ Strobel Family Investments, 2006 Wash App LEXIS 1136, 12-13 (12 June 2006). 
(1) the use is really public, (2) the public interest requires it, and (3) the property appropriated is necessary for that purpose' ${ }^{100}$

The landowner questioned whether the condemnation is 'necessary,' specifically arguing that the City might sell a portion of the property to a private developer, which would benefit that private entity and not the City. ${ }^{101}$ The court pointed out, however, that the City Council specifically determined that the property would be used only for public streets, public parks, or public parking. ${ }^{102}$ Moreover, the court explained that ' $[w]$ here property is taken, ... with the intention of using it for a certain purpose specified in the ordinance authorizing the taking, as was done in this case, the city, doubtless, has the authority to change said contemplated use to another and entirely different use, whensoever the needs and requirements of the city suggest. ${ }^{\prime 103}$ In holding that the city council's determination that the property was 'reasonably necessary and required' for the development, the court reasoned: "When it comes to such discretionary details as the particular land chosen, the amount of land needed, or the kinds of legal interests in that land that are necessary for the project, many Washington decisions have said that the condemnor's judgment on these matters will be overturned only if there is proof of actual fraud or such arbitrary and capricious conduct as would amount to constructive fraud'. Given the absence of actual or constructive fraud, the court held that the City's determination to condemn the entire property was necessary to facilitate a public use.

\section{iii. City of Norwood v Horney}

The Ohio Supreme Court was the first state supreme court to accept an eminent domain case after Kelo. ${ }^{104}$ In City of Norwood v Horney, the Ohio Supreme Court unanimously held that 'an economic or financial benefit alone is insufficient to satisfy the public-use requirement of [the Ohio Constitution]. ${ }^{105}$ In this case, the City of Norwood entered into a contract with Rookwood Partners Ltd, ('Rookwood') in order to redevelop the plaintiffs' neighborhood. When Rookwood could not negotiate the sales of certain properties the City initiated condemnation proceedings. Pursuant to the City code, an urban-renewal study was completed before the City instituted the eminent domain proceedings. The study concluded that the neighborhood was a 'deteriorating area' as that term is defined in the Norwood Code. ${ }^{106}$

\footnotetext{
100 Ibid, at 6. (citations omitted).

101 Ibid, at 8.

102 Ibid.

103 Ibid, at *9. (quotations and citations omitted).

${ }^{104}$ John Kramer and Lisa Knepper, 'Ohio Supreme Court Accepts Eminent Domain Abuse Case', 3 October 2005, http://www.ij.org/private_property/norwood/10_3_05pr.html.

105 City of Norwood v Horney, 853 NE2d 1115, 1142 (2006).

106 Ibid.
} 
At trial, the court found that the study 'contained numerous flaws and errors' and the City's planning director testified only that the neighborhood 'probably would' deteriorate or was in danger of deteriorating or becoming a blighted area. ${ }^{107}$ Based upon this evidence, the trial court found that the City abused its discretion insofar as it had found that the neighborhood was a 'slum, blighted or deteriorated area.' ${ }^{108}$ 'The court concluded, however, that the City did not abuse its discretion in finding that the neighborhood was a 'deteriorating area.' ${ }^{109}$ The landowners appealed.

In reversing the trial court's decision, the Ohio Supreme Court specifically declined to hold 'economic benefits alone to be a sufficient public use for a valid taking. ${ }^{110}$ The court found that analysis by the Supreme Court of Michigan in County of Wayne v Hathcock ${ }^{111}$ and the dissenting judges of the Supreme Court of Connecticut and the dissenting justices of the US Supreme Court in Kelo, are 'better models' for interpreting the Ohio Constitution. ${ }^{112}$ In applying the analysis therefrom, the court held that 'an economic or financial benefit alone is insufficient to satisfy the public-use requirement in the Ohio Constitution. Based upon that holding, any taking grounded solely on financial gain is void as a matter of law and the courts owe no deference to a legislative finding that the proposed taking will provide financial benefit to a community.' ${ }^{113}$ The court explained that '[a] lthough economic benefit can be considered as a factor among others in determining whether there is a sufficient public use and benefit in a taking, it cannot serve as the sole basis for finding such benefit. ${ }^{114}$

Next, the court turned to the City's eminent domain statute. The court determined that the void-for-vagueness doctrine applies to statutes that regulate the use of eminent-domain powers and that courts should apply 'heightened scrutiny' when reviewing such statutes. ${ }^{15}$ The court held that the use of the term 'deteriorating area' as a standard for determining whether private property is subject to appropriation was 'void for vagueness and offends due process rights because it fails to afford a property owner fair notice and invites subjective interpretation."116 The court found that 'deteriorating area' was a 'standardless standard' and that the City code 'merely recites a host of subjective factors that invite ad hoc and selective enforcement."117

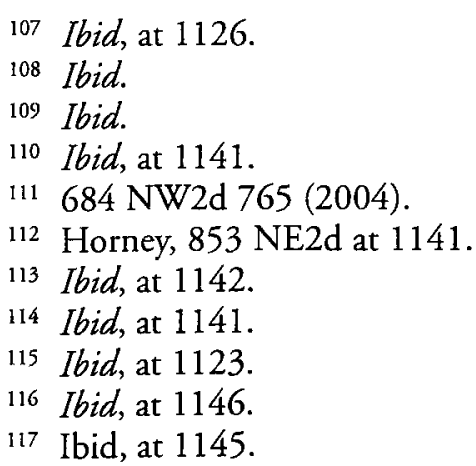


The court further held that in any event the term could not be used as a standard for a taking because it 'inherently incorporates speculation as to the future condition of the property into the decision ... rather than focusing that inquiry on the property's condition at the time of the proposed taking. ${ }^{\prime 18}$ The court reasoned that ' $[\mathrm{s}]$ uch a speculative standard is inappropriate in the context of eminent domain, even under the modern, broad interpretation of "public use." 119 Moreover, '[a] municipality has no authority to appropriate private property for only a contemplated or speculative use in the future. ${ }^{120}$

\section{B. Just Compensation}

Just compensation is an essential element of the valid exercise of the power of eminent domain. An individual has a fundamental and constitutional right to compensation when his land is taken for the public use. 'Compensation' as used in the constitutional provision as a limitation upon the power of eminent domain implies a full and complete equivalent (usually monetary) for the loss sustained by the owner whose land has been taken or damaged. Nothing short of actual payment constitutes just compensation. ${ }^{121}$ This applies to all property put to use by the condemning party (private land, swamp, etc). ${ }^{122}$ Restraint of use of property cannot be imposed, even for a temporary period without payment of compensation (however, reasonable conditions may be imposed). ${ }^{123}$

Just compensation is normally measured by the fair market value of the property at the time of the taking. It should put the owner of the condemned property in as good a position pecuniarily as if his property had not been taken. The emphasis is on justice, and the compensation system should not sacrifice justice for efficiency. The right to claim compensation is not dependent upon the mode of appropriation, nor need the condemnee be concerned in this respect whether the property is actually devoted to the purpose for which it was acquired. ${ }^{124}$

The constitutional provision obligating the condemnor to pay compensation is strictly construed in favor of the condemnee. Thus the owner's right to

118 Ibid, at 1146.

119 Ibid, at 1145 .

${ }^{120}$ Ibid. For an extended discussion of the 'Kelo Revolution' and its aftermath, see Nicole Stelle Garnett, 'The Neglected Political Economy of Eminent Domain', 105 Mich L Rev 101 (2006); Timothy J Dowling, 'How to Think About Kelo After the Shouting Stops', 38 Urb Law 191 (2006); Gideon Kanner, 'Kelo v New London: Bad Law, Bad Policy, and Bad Judgment', 38 Urb Law 201 (2006).

1213 Nichols on Eminent Domain $\$ 8.01$.

1221 Nichols on Eminent Domain $\$ 1.42[1]$; Peacock $v$ County of Sacramento, 77 Cal Rptr 391 (Cal Ct App 1969); Beidler v Sanitary District, 71 NE 1118 (Ill 1904); Lorio v Sea Isle City, 212 A2d 802 (NJ Super Ct Law Div 1965).

1231 Nichols on Eminent Domain $\$ 1.42[2]$.

1243 Nichols on Eminent Domain $\$ 8.01$. 
compensation is absolute and the condemnor has no right to impose conditions or qualifications thereon. Whenever private property has been taken or damaged for public use without compensation, the property owner may take action in a suit by reason of inverse condemnation (a de facto or common law taking). ${ }^{125}$ The adjudication of the right to condemn is made only after a hearing at which the owner/respondent/condemnee is entitled to be represented, and is the appropriate occasion for contesting the validity of the taking. ${ }^{126}$

\section{Due Process}

The principal bundle of rights held by an owner of real property about to be acquired by a governmental agency under the power of eminent domain fall into two categories: compensation and due process. Both derive from the US Constitution's 5th and 14th Amendments. Beyond these rights are rights, mainly procedural, conferred by statutes under which government agencies actually go about acquiring property by compulsory purchase. Once a proceeding in eminent domain is contested, then administrative process which attaches to such proceedings are usually guaranteed both by state and federal constitution and by state administrative procedure statutes. Among the procedural rights commonly held by owners of real property about to be condemned by a government agency:

(a) The right to notice. Actual notice is usually required with respect to affected landowners (those whose interest in property are being taken or damaged by the governmental action). Property owners with a more generalized interest in the condemnation are often held to be entitled to some notice, usually by publication. ${ }^{127}$

(b) The right to a hearing. If the matter is contested, then the right of the landowner is usually to a contested case hearing. This includes the right to call and cross-examine witnesses and present other evidence. Intervention in such hearings to do the same things depends on the degree of interest in the proceedings that a potential intervenor can show. The hearing, of course, may be before a court rather than an agency tribunal, depending upon the state statutory language setting out eminent domain procedures.

From a constitutional perspective, it is irrelevant what body (court or agency) actually provides the due process. ${ }^{128}$ Thus, for example, the Santa Cruz Redevelopment Agency in California condemned an easement for public parking over a private parking area after negotiations with the landowner failed, by first

1253 Nichols on Eminent Domain $\$ 8.01$.

1266 Nichols on Eminent Domain $\$ 26 A .05[1]$.

127 See In the Matter of the Decision of the State of South Dakota Water Management Board Approving Water Permit No 1791-2, 351 NW 2d 119, 123 (1984).

128 Ibid. See also Weiner $v$ State of Nebraska Department of Roads, 137 NW 2d 852 (1965). 
giving notice to the landowner, then holding a hearing, then adopting a resolution of public necessity, then filing a complaint in eminent domain in court, all within a 6 week period. The right to take was not decided by the trial court until 2 years later, however, only to be overturned by the California Court of Appeals three years later because the landowner's statutory right to raise certain objections at the trial had been violated. ${ }^{129}$ In the course of its opinion, the court set out the statutory rights of objection which all landowners in California have in compulsory purchase cases: ${ }^{30}$

a. The government agency is not authorized by statute to exercise the power of eminent domain for the purpose stated in the complaint;

b. The stated purpose is not a public use;

c. The agency does not intend to devote the property described in the complaint to the stated purpose;

$\mathrm{d}$. There is no reasonable probability that the agency will devote the described property to the stated purpose within seven years, or within 10 years where the property is taken pursuant to the Federal Highway Act of 1973, or such longer period as is reasonable;

e. The described property is not subject to the power of eminent domain for the stated purpose;

f. The described property is sought to be acquired pursuant to a statutory section on excess condemnation;

g. The described property is sought to be acquired pursuant to condemnation for a more necessary public use, but the defendant property owner has the right to continue the public use to which the property is appropriated, as a joint use;

h. Any other ground provided by law.

\section{Inverse Condemnation}

A landowner may recover just compensation for a taking of property even though condemnation proceedings, under the power of eminent domain, have not been instituted by the state. The process for doing so is aptly called inverse condemnation.' When the challenge is to 'public use,' as in Midkiff, the court can enjoin the action. If public use is not in issue, the action is for compensation. As the Court explained in United States $v$ Clarke: 'There are important legal and practical differences between an inverse condemnation suit and a condemnation proceeding. Although a landowner's action to recover just compensation for a taking by physical intrusion has come to be referred to as "inverse" or "reverse" condemnation, the simple terms "condemn" and "condemnation" are not

129 Santa Cruz County Redevelopment Agency v Izant, 43 Cal Rptr 2 d 366 (1995).

130 Ibid. 
commonly used to described such an action. Rather, a "condemnation" proceeding is commonly understood to be an action brought by a condemning authority such as the Government in the exercise of its power of eminent domain'. ${ }^{131}$

The phrase 'inverse condemnation' appears to be one that was coined simply as a shorthand description of the manner in which a landowner recovers just compensation for a taking of his property when condemnation proceedings have been instituted. As defined by one land use planning expert, inverse condemnation is ' a cause of action against a governmental defendant to recover the value of property which has been taken in fact by the governmental defendant, even though no formal exercise of the power of eminent domain has been attempted by the taking agency. ${ }^{132} \mathrm{~A}$ landowner is entitled to bring such an action as a result of 'the selfexecuting character of the constitutional provision with respect to compensation. ${ }^{133}$ A condemnation proceeding, by contrast, typically consists of an action by the condemnor to effect a taking and acquire title. The phrase 'inverse condemnation,' as a common understanding of that phrase would suggest, simply describes an action that is the 'inverse' or 'reverse' of a condemnation proceeding.

There are also important practical differences between condemnation proceedings and actions by landowners to recover compensation for inverse condemnation.' Depending upon the applicable statute, condemnation proceedings require various affirmative actions on the part of the condemning authority. On the other hand, to accomplish a taking by seizure, a condemning authority need only occupy the land in question. Such a taking thus shifts to the landowner the burden to discover the encroachment and to take affirmative action to recover just compensation.

Likewise, the choice of the condemning authority to take property by physical invasion rather than by a formal condemnation action may also have important monetary consequences. The value of property taken by a governmental body is ascertained as of the date of taking. ${ }^{134}$ In a condemnation proceeding, the taking generally occurs sometime during the course of the proceeding, and thus compensation is based on a relatively current valuation of the land. ${ }^{135}$ When a taking occurs by physical invasion, on the other hand, the usual rule is that the time of the invasion constitutes the act of taking, and '[i]t is that event which gives rise to the claim for compensation and fixes the date as of which the land is to be valued.' ${ }^{136}$

131 States $v$ Clarke, 445 US 253, 255 (1980) (emphasis in original).

132 Donald G Hagman, Urban Planning and Land Development Control Law (St Paul: West Publishing Co, 1971), p 328 (emphasis added).

1336 Nichols on Eminent Domain $\$ 25.41$.

134 United States v Miller, 317 US 369, (1943).

135 See Louis Orgel, 1 Valuation in Eminent Domain $\$ 21$, n 29 (2nd ed, 1953).

136 United States v Dow, 357 US 17 (1958). 


\section{Regulatory Takings}

The taking of private property without compensation is unconstitutional under the Fifth Amendment to the US Constitution ('nor shall private property be taken for public use, without just compensation.'). While arguably drafted principally to protect private landowners from physical takings without compensation, since at least 1922 and the decision of the US Supreme Court in Pennsylvania Coal Co v Mahon, ${ }^{137}$ a regulation of land which goes 'too far' is also a taking for which government must pay compensation. There are two applicable branches of regulatory takings: categorical or total, and partial.

\section{A. Per Se or Total Takings: The Lucas Rule}

A land use regulation totally takes property by regulation when it leaves the landowner without 'economically beneficial use' of land. The land may have value. Indeed, it may even have some limited, 'salvage' uses such as for walking or picnicking. But if it has no economically beneficial use, then the government must pay for the land as if it had condemned it, or lift the offending regulation and potentially pay for the time during which the unconstitutional regulation affected the use of the relevant land. These are the rules of Lucas $v$ South Carolina Coastal Council, ${ }^{138}$ and First English Evangelical Lutheran Church of Glendale $v$ County of Los Angeles. ${ }^{139}$

In Lucas, a state coastal zone protection statute prevented David Lucas from constructing two beachfront houses on two separate lots. The statute prevented development forward of a beach line in order to protect coastal habitat, plant, animal and marine species, the natural environment and tourism. Remaining legal uses included walking, limited camping and picnicking. The US Supreme Court reversed the supreme court of South Carolina, holding that a regulation which removes all productive or economically beneficial use from a parcel of land is a regulatory taking requiring compensation under the Fifth Amendment. The Court emphasized use, not value, in holding that the remaining permitted uses were not economically beneficial. The court imposed no limitations on this per se, categorical rule except for two exceptions briefly noted below. Observing that too often land use regulations having as their principal purpose the preservation of the environment have forced a single landowner to bear the burden of such public benefits, the Court said: 'Where the State seeks to sustain regulation that deprives land of all economically beneficial use, we think it may resist compensation only if the logically antecedent inquiry into the nature of the owner's estate shows that the proscribed use interests were not part of his title to begin with'. ${ }^{140}$

\footnotetext{
137260 US 393 (1922).

138505 US 1003 (1992).

139 482 US 304 (1987).

140 Lucas, 505 US 1003 at 1027.
} 
Closely following this reasoning in Lucas, a Maryland court held that an open space zoning category effectively foreclosed all economically viable use when applied to private property, resulting in a total taking: 'While a strong argument can be made that the statutory scheme here at issue ... is for the common good, that argument, if resolved favorably to the County, does not, under Lucas, resolve the matter. Even if it were for the common good, it still may cause an unconstitutional taking if it, as it does in the case sub judice, results in the loss of all viable economic uses'. ${ }^{141}$

On the other hand, a Florida appeals court held that a recreational use was sufficiently economically beneficial to take a case out of the per se takings category of regulatory takings because that was one of the uses being made of the subject parcel and there was some evidence that this was one of the reasons the landowner had acquired the parcel. ${ }^{142}$ Similarly, an Ohio appeals court held that the denial of a conditional use permit for mineral extraction was not a total regulatory taking since the owner was not denied all economically viable use where the property was zoned for many other uses and could be sold to a developer who could use the property in a manner consistent with zoning laws. ${ }^{143}$

The US Supreme Court set out two exceptions to its categorical rule-situations in which the proscribed use interests would not be a part of the owner's title to begin with: nuisance and background principles of a state's law of property.

\section{The Nuisance Exception}

If the law of the jurisdiction would allow neighbors or the state to prohibit the proposed uses of land because they would constitute either public or private nuisances, then government could prohibit them without providing compensation. This is because such nuisances are always unlawful and are never part of a landowner's title to begin with, so prohibiting them would not deprive a landowner of a property right. The Court gave as examples laws that would prevent the construction of a nuclear power plant on an earthquake fault line, or the filling of lakefront land so as to raise the water level and flood neighboring land.

While most nuisance exceptions have generally been applied to mining cases ${ }^{144}$ at least one (sharply divided) court has upheld the denial of a permit to construct a marina even if the owner were left with no economically beneficial use, on the ground that the additional traffic generated would constitute a nuisance and

${ }_{1+1}$ Steel $v$ Cape Corporation, 677 A2d 634, 645 (Md Ct Spec App 1996).

142 State of Florida, Department of Envtl Protection v Burgess, 772 So $2 \mathrm{~d} 540$ (Fla Dist Ct App 2000).

143 State ex rel Shelly Materials, Inc v Clark County Bd of Comm'r, 2005 Ohio 6682 (Ohio Ct App 2005).

144 See, eg, Rith Energy, Inc v United States, 44 Fed Cl 366 (Fed Cl 1999); Kinross Copper Corp v Oregon, 98 P2d 833 (Or App 2001); Machipongo Land and Coal Company, Inc v Commonwealth, $799 \mathrm{~A} 2 \mathrm{~d} 751$ ( $\mathrm{Pa} 2002$ ) (holding that the danger to public waterways from mining pollution constituted a public nuisance). 
therefore constitute an exception to the categorical rule. ${ }^{145}$ The Florida Supreme Court has also extended 'nuisance exception' status to the closing of a motel used for prostitution and drug dealing, though not to an apartment used occasionally for drug transactions, which the City of Miami also closed, in Keshbro Inc $v$ City of Miami. ${ }^{146}$ To the same effect, State $v$ Rezcallah, ${ }^{147}$ holding padlocking of property for one year as a result of drug activity not to be a nuisance exception and not substantially advancing a legitimate state interest in curtailing the use and sales of drugs.

\section{The Background Principles Exception}

Likewise, if a regulation is consistent with a background principle of a state's law of property, again there would be no deprivation of a cognizable right in property. While the Court gave no examples of such a background principle, customary rights and land held subject to public trust are emerging as such background principles in several jurisdictions.

\section{a. The Public Trust Doctrine as a Background Principle}

Broadly stated, the public trust doctrine provides that a state holds public trust lands, waters and living resources in trust for the benefit of its citizens, establishing the right of the public to fully enjoy them for a variety of public uses and purposes. ${ }^{148}$ Implied in this definition are limitations on the private use of such waters and land which are impressed with the public trust, as well as limitations on how the state may transfer interests in such land and water, particularly if such transfer will prevent public use. Such definitions and duties analytically flow from the dual nature of title in public trust lands and water. On the one hand, the public has the right to use and enjoy the land and water-the res of the public trust-for such activities as commerce, navigation, fishing, bathing and related public purposes. This is the so-called jus publicum. On the other hand, since fully one-third of public trust property is reportedly in private hands rather than public, private property rights coexist with public rights in much land and water subject to the public trust doctrine. This is the so-called jus privatum. ${ }^{149}$

The issue, of course, is the extent to which the public trust doctrine can legally eliminate private property rights without compensation required by the US Constitution's Fifth Amendment. To the extent that such rights are recognized, they would constitute a diminution of the fee simple much like the recognized private limitations on fee simple such as leaseholds, easements, and the burdens of

145 Windward Marina, LLC v City of Destin, 743 So2d 635 (Fla Dist Ct App 1999).

146801 So2d 864 (Fla 2001).

147702 NE2d 81 (Ohio 1998).

148 David Slade, Putting the Public Trust Doctrine to Work, (Coastal States Organization, 2nd ed, 1990), p 4.

149 Ibid, at 2, 230. 
covenants running with the land. These are interests held by strangers to the basic title of the landowner, and are therefore not 'part of his title to begin with.' In the same fashion, if public trust rights are valid, then these also represent interests in private land which are not part of the owner's title to begin with-a valid, background principle of property law which provides an exception to the per se categorical regulatory takings rule of the Lucas case.

The issue of regulatory taking in connection with public trust arises most frequently when a state court or legislature 'reaffirms' the public's trust 'rights' on private property. This occurs when a state:

1. imposes restrictions on privately-held trust lands;

2. requires public access across private land or access to trust lands or water;

3. expands the scope of public activities permitted under the guise of public trust rights. Most public trust lands are submerged, tidal or water-flowed. However, some courts expand the application of public trust doctrine to 'dry-sand' and other more useable and developable areas.

Many courts find the public trust doctrine applies at least to submerged and tide-flowed lands. Thus, in Illinois Central $R R$ Co, v Illinois, ${ }^{150}$ the US Supreme Court held that the Illinois legislature could not transfer in fee simple land under Lake Michigan because that land was held in public trust for the people of the state. However, the state could sell small parcels of public trust land the use of which would promote the public interest (docks, piers, wharves) so long as this did not impair the public interest in the lake and the remaining submerged land. In Phillips Petroleum Co v Mississippi, ${ }^{151}$ the Court extended the public trust to all lands under waters influenced by the ebb and flow of the tides.

Courts also have rejected takings claims brought by landowners whose plans for development are thwarted by the application of the public trust doctrine. In Orion Corp $v$ State, ${ }^{152}$ the court held that a landowner could have no investmentbacked expectations in its land development plans, frustrated after purchase by a series of coastal and tideland protective statutes, because all of Washington's shoreline was impressed with a public trust which, of course, could not be alienated. However, the court noted that the statutes and regulations were more restrictive than would result from a reasonable application of the public trust doctrine alone, and that to the extent they left the landowner without any economically viable use of the land, a regulatory taking would occur. A federal court in Madison v Graham ${ }^{153}$ upheld what it considered to be a 'narrow' use by the public of streams and streambeds for recreational uses against a claim of takings by a landowner brought

\footnotetext{
150146 US 387 (1892).

151484 US 469 (1988).

152747 P2d 1062 (Wash 1987).

153126 F Supp 2d 1320 (D Montana 2001).
} 
on a 'right to exclude' theory. So also the court in National Audubon Society $v$ Superior Court of Alpine County, ${ }^{154}$ rejected a private takings claim on public trust grounds.

Perhaps the biggest extension of the public trust doctrine is represented by Matthews $v$ Bay Head Improvement Ass $n,{ }^{155}$ extending the public trust doctrine to private dry sand beach areas for both access to and limited use of the ocean and foreshore. The court held that the public rights to the water would be meaningless unless the public were guaranteed both access and a place to rest intermittently. The Supreme Court of Wisconsin even extended the public trust doctrine to a weedland (which became a bird sanctuary) created by the property owner in the course of development in $R W$ Docks \& Slips $v$ Wisconsin. ${ }^{156}$ Finally, in a pre-Lucas case, a Texas court of appeals held that when a hurricane moved a beach vegetation line hundreds of feet, landowner's home was now on the 'public' beach easement (presumably public trust) and so could not be rebuilt.

Also building upon the growing body of law finding private land impressed with a public trust may be regulated with impunity as a 'background principles' exception is McQueen v South Carolina Coastal Council. ${ }^{157}$ McQueen purchased two noncontiguous lots adjacent to man-made canals in the early 1960's, but left them unimproved until the early 1990's, by which time neighboring lots were improved with bulkheads and retaining walls, while McQueen's had 'reverted' to tidelands. When McQueen applied to the appropriate state authority for permission to backfill his lots and build his own bulkhead, the state denied the requisite permit on the ground that it would destroy the 'critical environment' on those lots. Both a special master and the court of appeals and supreme court agreed (eventually) that the denial left the lots without any economically beneficial use and so resulted in a total taking under Lucas.

Initially, the state supreme court nevertheless denied relief because it found 'confusion' over whether the 'investment-backed expectations' standard-a 'partial takings' standard as appears below-applied to total takings. Nevertheless, the court eventually denied compensation on the ground that South Carolina holds 'presumptive title' to land below the high water mark and moreover 'wetlands created by the encroachment of navigable tidal water belong to the state.' Moreover, the state also has 'exclusive right to control land below the high water mark for the public benefit... and cannot permit activity that substantially impairs the public interest in marine life, water quality, or public access.' The court then held that so much of McQueen's lots as had 'reverted to tidelands' were 'public trust property subject to control of the State.' 
Not all courts have been so quick to accept extensions of the public trust doctrine, and even those which accept it within its traditional limits often permit limited private use of public trust resources. Thus, in Kootenai Environmental Alliance, Inc, $v$ State Board of Land Commissioners, ${ }^{158}$ the court approved the leasing of state lands impressed with a public trust to a private club for the construction, maintenance and use of private docking facilities on a bay in a navigable lake, on the ground that such lease and use was 'not incompatible' with the public trust imposed on the property.

Moving to applying the public trust doctrine to private land, the court in Bell $v$ Town of Wells Beach, ${ }^{159}$ held that attempts to cross private land to reach public land for recreational purposes in accordance with the state's Public Trust and Intertidal Land Act resulted in a taking of private property without compensation. Another court also refused to expand statutory declarations of public trust to permit access across private land to reach inter-tidal lands in Opinion of the Justices: ${ }^{160}$ 'The permanent physical intrusion into the property of private persons, which the bill would establish, is a taking of property within even the most narrow construction of that phrase possible under the Constitutions of the Commonwealth and the United States ... The interference with private property here involves a wholesale denial of an owner's right to exclude the public'. ${ }^{161}$

To the same effect is Opinion of the Justices (Public Use of Coastal Beaches), ${ }^{162}$ in which the court held that a new statute providing for access to tide-flowed public trust shoreline across abutting private land was a taking: 'When the government unilaterally authorized a permanent public easement across private lands, this constitutes a taking requiring compensation... Because the bill provides no compensation for the landowners whose property may be burdened by the general recreational easement established for public use, it violates the prohibition contained in our State and Federal Constitutions against the taking of private property for public use without just compensation. Although the state has the power to permit a comprehensive beach access and use program by using its eminent domain power and compensating private property owners, it may not take property rights without compensation by legislative decree. ${ }^{163}$

The same court drove home these advisory points when five years later it considered an actual case and controversy ${ }^{164}$ in which forty beachfront property owners sued the state on regulatory taking grounds when the state moved a public trust lands boundary line inland from the mean high water mark: 'Having

671 P2d 1085 (Idaho 1983).

557 A2d 168 (Me 1989).

160313 NE2d 561 (Mass 1974).

161 Ibid, at 568.

162649 A.2d 604 (NH 1994).

163 Ibid, at 611.

164 Purdie v Attorney General, 732 A2d 442 (NH 1999). 
determined that New Hampshire common law limits public ownership of the shorelands to the mean high water mark, we conclude that the legislature went beyond common law limits by extending public trust rights to the highest high water mark ... Because (the statute) unilaterally authorizes the taking of private shoreland for public use and provides no compensation to landowners whose property has been appropriated, it violates (the State Constitution) and the Fifth Amendment of the Federal Constitution against the taking of property for public use without just compensation.... Although it may be desirable for the State to expand public beaches to cope with increasing crowds, the State may not do so without compensating affected landowners'. ${ }^{165}$

\section{b. Customary Law as a Background Principle}

Customary rights in land usually arise when a particular group or class of persons can show a right to do a particular thing or practice upon land which they neither own nor otherwise possess the right to do, based upon past and unchallenged practice extending back over some time. The claimant to the custom would, in other words, be a trespasser on the land of another, but for the custom. The reception of customary law in the United States was originally chilly despite its common, though restricted, use in England. The reasons had much to do with the restrictions on use resulting from the application of the doctrine, and the difficulties in terminating a custom, once found or declared. This latter was of particular concern to the legendary John Chipman Gray, of future interests and the rule against perpetuity fame, whose concerns about custom were as follows: 'Especially it should be remembered that they cannot be released, for no inhabitant, or body of inhabitants, is entitled to speak for future inhabitants. Such rights form perpetuities of the most objectionable character. ${ }^{166}$

An early 19 th century court put it well in Ackerman $v$ Shelp, ${ }^{167}$ in which a custom was alleged to permit inhabitants of a town an easement to reach a riverbank: '[I]f [this] custom...is to prevail according to the common law notion of it, these lots must lie open forever to the surprise of unsuspecting owners, and to the curtailing [of ] commerce, in its more advanced state, of the accommodation of docks and wharves, when perhaps a tenth part of the lots now open would be all sufficient as watering places; a principle of such extensive operation ought not to be strained beyond the limits assigned to it in law. If [the]public convenience requires highways to church, school, mill, market or water, they are obtainable in a much more direct and rational manner under statute than by way of immemorial usage and custom'. ${ }^{168}$

168 Ibid, at 130-131. 
Despite this cautionary background concerning the problems associated with custom, courts in the United States have declared public rights or rights of a huge class of strangers to cross private land based exclusively on some version of customary law. Perhaps the most famous of these is Oregon ex rel Thornton $v$ Hay, ${ }^{169}$ in which the plaintiffs sought to prevent the Hays from constructing improvements on the dry-sand beach portion of their lot between the high water line and the upland vegetation line. Rejecting the proffered bases of prescriptive rights and easements, the court decided in favor of the plaintiffs, sua sponte, extending customary rights to virtually the entire population of Oregon: 'Because many elements of prescription are present in this case, the state has relied upon the doctrine in support of the decree below. We believe, however, that there is a better legal basis for affirming the decree. The most cogent basis for the decision in this case is the English doctrine of custom. Strictly construed, prescription applies only to the specific tract of land before the court, and doubtful prescription cases could fill the courts for years with tract-by-tract litigation. An established custom, on the other hand, can be proven with reference to a larger region. Ocean-front lands from the northern to the southern boundary of the state ought to be treated uniformly'. ${ }^{170}$

Lest the reach of custom be misunderstood in a per se, total regulatory takings context under Lucas, the same court in Stevens $v$ City of Cannon Beach, ${ }^{171}$ responded to a takings claim over the refusal of local government to grant a seawall permit on customary rights interference grounds that the customary law of Oregon preventing such construction was a background principle of state property law and therefore an exception to the categorical total takings rule when a property owner was left with no economically beneficial use of his land.

In two landmark cases, ${ }^{172}$ the Hawaii Supreme Court expanded previous rulings to provide that native Hawaiians are entitled to exercise their state-constitutionallyprotected traditional and customary rights on land which is 'not fully developed' whether or not such native Hawaiians actually reside or own property on their land, provided they can show they have traditionally done so.

The two cases deal specifically with access rights and gathering rights, but, without going into specific definitions, the supreme court indicated it did not mean to restrict the definition of traditional and customary rights to these two categories. However, in a subsequent decision, ${ }^{173}$ the supreme court modified its earlier decisions by holding that in order to exercise such traditional and customary rights, a native Hawaiian needed to prove that such a right existed geographically where claimed, and that such native Hawaiian was specifically entitled to exercise

Ibid, at 676.

171854 P2d 449 (Or 1993).

172 Pele Defense Fund v Paty, 837 P2d 1247 (Haw 1992); Public Access Shoreline Hawaii v Hawaii County Planning Commission, 903 P2d 1246 (Haw 1995).

173 Hawaii v Hanapi, 970 P2d 485 (Haw 1998). 
that right. In other words, such traditional and customary rights as are protected by the Hawaii state constitution do not extend to every native Hawaiian and to every parcel of land in the state. The second decision further specifically held that such rights can only be exercised on undeveloped or less than fully developed land, specifically holding that on land which is residentially-zoned with existing dwellings, improvements and infrastructure it is 'always inconsistent' to permit the practice of such rights. The subject parcel in the case consisted of several acres with but one dwelling.

\section{c. Statutes as Background Principles}

More troubling is the occasional case finding background principles in preexisting statutes, which would broaden the exception considerably and likely contrary to the implications of Lucas which, after all, did involve the application of a statute. Thus, for example, the supreme court of New Hampshire held that a 'positive law' could be construed as a background principle if it were passed prior to the landowner's acquisition of the subject parcel. ${ }^{174}$ Finally, in a strange twist on the law of background principles exceptions, a court of appeals in Arizona denied a takings claim by a landowner over whose property flowed (by state permit) water for another landowner whose use of property (underground storage) depended upon flowing streamwater across his private stream. The court held that the doctrine of prior appropriation, upon which the permit was based, was a background principle of Arizona's water law, rendering such a takings claim impossible under a Lucas exception.

\section{3. 'Use' vs 'Value' in Total Regulatory Takings}

There is dicta in the recent US Supreme Court case of Tahoe-Sierra Preservation Council, Inc $v$ Tahoe Regional Planning Agency, ${ }^{175}$ which emphasizes value rather than use in the application of the Lucas categorical rule, but it is clearly and unequivocally dicta. The dicta is not surprising since the author of that opinion filed a vigorous dissent to the Lucas categorical taking rule decision. Some state courts also use value rather than use in deciding whether to apply the categorical total regulatory taking rule. ${ }^{176}$ If the dicta should become the holding of a later case, it would pretty much eviscerate the categorical total taking rule since there is nearly always some value left in a parcel, whatever the land use restriction.

However, this is an unlikely interpretation given the recent US Supreme Court decision in Lingle $v$ Chevron ${ }^{177}$ in which the Court set out at length its current takings jurisprudence, including the Lucas rule as originally 'written.' The Court

174 Sanderson v Town of Candia, 787 A2d 167 (NH 2001).

175535 US 302 (2002).

176 See, eg, MC Associates v Town of Cape Elizabeth, 773 A2d 439 (Me 2001) and Fichter ex rel $v$ State Board of Environmental Protection, 2000 WL 33676710 (Me Super Ct 1 May 2000).

177544 US 528 (2005). 
reviews four distinct categories of takings by regulation - two rare 'per se', one partial (by far the more common) and unconstitutional conditions, none of which, the Court is careful to point out, are affected by its holding in Lingle: "We emphasize that our holding today-that the 'substantially advances' formula is not a valid takings test - does not require us to disturb any of our prior holdings. ${ }^{178}$ While not a part of the rule of the case, this summary does bear the stamp of a unanimous Court, which in itself is a rarity in recent Supreme Court takings jurisprudence. It is therefore worth setting out in some detail.

The court set out the two classes of taking: First, permanent physical invasion of property-however minor-for which the State must provide compensation. For this proposition, the Court cited its 1982 holding in Loretto $v$ Teleprompter Manhattan CATV Corp, ${ }^{179}$ in which the Court struck down a state law requiring landlords to permit cable companies to install cable facilities on apartment buildings. ${ }^{180}$ Second, where government regulations completely deprive a landowner of 'all economically beneficial use' of the land, government must pay compensation for a total regulatory taking except to the extent nuisance or the background principles of a state's law of property restrict the landowner's intended use. ${ }^{181}$ This is, of course, the rule established in Lucas $v$ South Carolina Coastal Council, ${ }^{182}$ where two lots in a developed beachfront residential subdivision were rendered unbuildable by a state coastal protection statute prohibiting any construction thereon. The Court criticized the decision in Tahoe-Sierra Preservation Council v Tahoe Regional Planning Agency, ${ }^{183}$ making it clear that, rare as the deprivation of all economically beneficial use will be, the Lucas per se rule is alive, well, and applicable when government regulation results in such a total deprivation of use. For the rest, as the Lucas majority readily concurred, Penn Central Transportation Company $v$ City of New York ${ }^{184}$ sets out the criteria for the more common partial taking by governmental regulation, discussed in Part $\mathrm{C}$ below.

\section{B. 'Temporary' Regulatory Takings}

The same Tahoe-Sierra opinion affected slightly the application of the rule in First Lutheran cited above. There, the Court held that a temporary taking, once proved,

$178 \mathrm{Ibid}$, at 545 . For an extensive discussion of the regulatory takings findings in Lingle, see RS Radford, 'Just A Fleshwound? The Impact of Lingle v Chevron on Regulatory Takings Law', 38 Urb Law 437 (2006); Daniel A Jacobs, 'Indigestion from Eating Crow: The Impact of Lingle v Chevron USA, Inc on The Future of Regulatory Takings Doctrine', 38 Urb Law 451 (2006).

179458 US 419 (1982).

180 Ibid, at 441.

181 Lingle, 544 US 528 at 538.

182505 US 1003 (1992).

183535 US 302 (2002) (in an opinion written by Justice Stevens who dissented vigorously from the Lucas majority opinion).

184438 US 104 (1978). 
requires compensation, particularly where, as there, the offending regulation was conceded for the sake of argument to be unconstitutional. The Tahoe-Sierra case merely holds, again very narrowly, that a 3-year moratorium under the explicit circumstances of the case was not always such a temporary taking. The Court was careful to note that a moratorium might well be a regulatory taking under the First Lutheran rule in some circumstances, but not in the situation presented in TahoeSierra (moratorium on development pending studies and regulations promulgated by a bi-state agency designed to preserve the clarity of Lake Tahoe). Mills Land \& Water Co $v$ City of Huntington Beach provides a good example. ${ }^{185}$ There, a California court of appeals found a 20-year delay in obtaining local coastal zone program approval to be a temporary taking by regulation. In Pettro $v U S,{ }^{186}$ the federal court of claims held the prevention of mining for 2 years during the pursuit by the government of a quiet title action amounted to a temporary taking requiring compensation.

\section{Partial Takings}

A partial taking by regulation occurs when a land use regulation deprives a landowner of use and value beyond the normal reduction, if any, caused by the necessary exercise of the police power for the health, safety and welfare of the people, but stops short of depriving the owner of all economically beneficial use. The government's rationale for the regulation and the economic effect of the regulation on the landowner are critical factors which a reviewing court weighs in deciding whether a landowner has suffered a partial taking of property. Partial takings are more common than total takings, but the standard-a balancing test among the various factors-is somewhat more difficult to apply. As the Lucas case suggested in footnote eight of its opinion, an owner who has suffered less than a full deprivation of economically beneficial use '...might not be able to claim the benefit of our categorical formulation, but, as we have acknowledged time and again, ' $[t]$ he economic impact of the regulation and...the extent to which the regulation interfered with the distinct investment-backed expectations' are keenly relevant to the takings analysis generally.'

The case which the Court cites and from which it quotes above is Penn Central Transportation Co v New York City, ${ }^{187}$ in which the Court set out the framework for deciding partial regulatory taking cases. The Court there upheld New York City's Landmark Preservation Law, which effectively prohibited Penn Central from constructing a fifty story office building over Grand Central Station, which Penn Central owned. Penn Central claimed that the designation of the station as a historic

18589 Cal Rptr 2 d 52 (Cal Ct App 1999), rehearing granted, depublished on 14 December 1999 , subsequent opinion on rehearing not for publication, remanded on 21 June 2000.

187438 US 104 (1978). 
landmark and the prohibition of its development plans constituted a taking of its property without just compensation under the Fifth and Fourteenth Amendments to the US Constitution. Before reaching the merits of the case, the Court suggested 'several factors' which have 'particular significance' when it engages in 'these essentially ad hoc, factual inquiries':

1. The economic impact of the regulation on the claimant and, particularly, the extent to which the regulation has interfered with the distinct, investmentbacked expectations;

2. The character of the governmental action;

3. Whether the taking is physical or if 'the interference arises from some public program adjusting the benefits and burdens of economic life to promote the common good. ${ }^{188}$

Adjusting the benefits and the burdens, the relevant part of the third criteria, is probably of little importance after Lucas given the Court's language there excoriating regulation which merely confers a public good and for which the Court clearly states the public as a whole should pay rather than a single landowner. That leaves the economic effect on the landowner and the character of the government's action as the primary focus of a partial regulatory taking case.

\section{Economic Effect on the Landowner and Frustration of Investment- Backed Expectations}

As an initial matter, Courts are not consistent in dealing with the most critical part of the 'economic effects' criterion: the investment-backed expectations of the landowner. There are now two characterizations of these expectations: 'distinct,' which the Court used in Penn Central, and 'reasonable,' which seems to have been engrafted later in a different context. ${ }^{189}$ The distinction is worth examining briefly.

There is a difference between 'distinct' and 'reasonable' investment-backed expectations. Distinct expectations are those which are clearly defined and articulated. Reasonable expectations are those which, measured against some objective standard, are rational for a landowner to hold under the circumstances of the case, whether or not they are distinct. Using the latter characterization permits a court to examine the factual context in which a landowner's expectations arise, including, arguably, whether the landowner had notice of the offending regulations when purchasing the property or formulating plans for development.

While many courts treat frustration of investment-backed expectations simply as a subset of economic effect, some courts go to great pains to separate the two. So it is in a recent decision of the Court of Claims in Cane Tennessee Inc, $v$ US. ${ }^{190}$

\footnotetext{
188 Ibid, at 124.

189 See Kaiser Aetna v United States, 444 US 174 (1979).

$19057 \mathrm{Fed} \mathrm{Cl} 115$ (Fed Cl 2003).
} 
In considering the extent of a regulatory taking, if any, on several of plaintiff's parcels following denial of certain surface mining permits, the court found a diminution of value of $49.6 \%$ of the relevant parcel (relevant parcel analysis in this case is discussed below and is instructive). Citing various cases showing, first, that the US Supreme Court has denied taking claims where the percentage of loss has been 'comparable or greater' and second that a plaintiff must show 'serious financial loss' for there to be a taking, the court held that the percentage of loss was too small to decide this factor in plaintiff's favor.

Turning then to investment-backed expectations, the court then found them to be minimal since plaintiff was involved in a high-risk industry (coal-mining) even though plaintiffs had no experience in coal-mining, because plaintiff had been advised in a financial services report that the required permits might not be obtainable. This made it difficult for plaintiff to successfully claim that plaintiff 'actually believed in a certain outcome and entered into the program in reliance on it.' The court then specifically held that 'Because a reasonably prudent investor could not have believed that its investment was without regulatory risk, [plaintiff] cannot now claim that it had reasonable investment-backed expectations.' Had the standard been 'distinct' rather than 'reasonable' the court might well have reached a different result on this criterion in the partial takings analysis.

\section{Character of the Governmental Action}

This standard has also 'morphed' into something different from the Court's original meaning in Penn Central. As the Hodel case cited in the preceding subsection indicates, it no longer means whether the taking was physical or regulatory (what the Court clearly meant in Penn Central) but rather the police power basis for the governmental action. Thus, the 'extraordinary' nature of the governmental action in Hodel helped persuade the Court that a partial regulatory taking had occurred. So also a court in Maine emphasized the importance of the character of the governmental police power action in preserving sand dunes (citing Penn Central) in Fichter ex rel $v$ State Board of Environmental Protection. ${ }^{191}$ Finally, in the aforementioned Cane Tennessee case, the court examined the character of the governmental action and found that although aesthetics may have been a factor in the denial of the requisite permits, there was enough evidence that they were denied in part over concerns that surface mining on the relevant parcels would create hazards dangerous to life and property, in particular with respect to potential landslides. This factor, then, was at best a wash.

\section{Legitimate State Interest}

Finally, some courts decided regulatory takings cases under the 'legitimate state interest' prong of the US Supreme Court's decision in Agins v City of 
Tiburon. ${ }^{192}$ Thus, in State ex rel. Shemo $v$ City of Mayfield Heights, ${ }^{193}$ the Ohio supreme court held that the city lacked any legitimate governmental health, safety or welfare concerns in support of a planned development reclassification of realtor's land which restricted it to single-family uses, and therefore the classification did not substantially advance any legitimate city police power interest. ${ }^{194}$

However, in 2005, the US Supreme Court eliminated 'legitimate state interest' as an independent ground for finding a taking under the Fifth Amendment, leaving it as a ground for relief only under the 14th Amendment to the US Constitution and its 'due process' clause. In Lingle $v$ Chevron USA Inc, ${ }^{195}$ the US Supreme Court abolished the 'substantially advances a legitimate state interest' threshold standard for determining when a land use regulation becomes a taking under the Fifth Amendment to the US Constitution. ${ }^{196}$ First established in the Court's 1980 decision, Agins $v$ City of Tiburon, ${ }^{197}$ the standard was occasionally used by lower courts, particularly in California, to invalidate regulations appearing to be devoid of any identifiable governmental purpose. ${ }^{198}$ As Justice Kennedy writes in his concurring opinion, the standard still applies in 14th Amendment regulatory takings challenges and, of course, is irrelevant to physical takings where the question is whether government acquires property by eminent domain for the constitutionallyrequired public use. ${ }^{199}$ The opinion - which is unanimous - is important, however, for the Court's summary of present regulatory taking law, at least as applied to disputes involving the regulation of property.

In Agins, the Court held that 'the application of a general zoning law to a particular property effects a taking if the ordinance does not substantially advance a legitimate state interest or denies an owner economically viable use of his land[.]'200 Aginses had facially challenged City zoning regulations which limited

192 Agins $v$ City of Tiburon, 447 US 255 (1980). See also State ex rel. Shemo $v$ City of Mayfield Heights, 765 NE2d 345 (Ohio 2002); choolcraft Egg, Inc $v$ Schoolcraft Township, 2000 WL 33409627 (Mich Ct App Aug 11, 2000); Cwynarv City \& County of San Francisco, 109 CalRptr2d 233 (Cal Ct App 2001); Sopsich v Charter Township of Milford, No 177033, 1996 WL 33362268 (Mich Ct App 23 July 1996); $R$ \& $Y$, Inc v Anchorage, 34 P3d 289 (Alaska 2001).

193765 NE2d 345 (Ohio 2002).

194 See also Schoolcraft Egg, Inc v Schoolcraft Township, 2000 WL 33409627 (Mich Ct App 11 Aug 2000); Cuynar v City \& County of San Francisco, 109 Cal Rptr 2d 233 (Cal Ct App 2001); Sopsich v Charter Township of Milford, No 177033, 1996 WL 33362268 (Mich Ct App 23 July 1996); $R \& Y$, Inc $v$ Anchorage, 34 P3d 289 (Alaska 2001).

195544 US 528 (2005).

196 Ibid, at $544-46$.

197447 US 260 (1980).

198 Lingle, 544 US 528 at 531.

199 Ibid, at 548-49 (Kennedy J, concurring).

200 Agins, 447 US 260 at 260 (citing Penn Central Transp Co v New York City, 438 US 104, 138 , n 36 (1978)). 
the type of structures permitted on their hilltop land from one to five singlefamily residences. ${ }^{201}$ While the Court held that they suffered no regulatory taking as a result of the ordinance, ${ }^{202}$ it set out the aforementioned standard for when a regulation became a taking under the Fifth Amendment. Relatively few subsequent cases cited the Agins decision, but when they did, it was for the 'stand-alone' requirement that to pass muster under a Fifth Amendment regulatory takings challenge, a government regulation must substantially advance a legitimate state interest. $^{203}$

The 'stand alone' requirement or test was the basis for both the federal district and circuit courts in Lingle to strike down Hawaii's rent cap statute for failure to advance a legitimate state interest. ${ }^{204}$ Lingle has nothing to do with the use of land. It concerned the retail price of gasoline in Hawaii, which is demonstrably higher than the mainland at most times. The Act 257, which the Hawaii legislature enacted in June of 1997, and which was codified at HRS $\$ 486 \mathrm{H}-10.4$, prohibits oil companies from converting existing lessee-dealer stations to company-operated stations and from locating new company-operated stations in close proximity to existing dealer operated stations. ${ }^{205}$ It also limits the rent that an oil company may charge a lessee-dealer to $15 \%$ of the dealer's gross profits from gasoline sales plus $15 \%$ of gross sales of products other than gasoline. ${ }^{206}$

The statute is, in layman terms, a rent cap. Chevron immediately challenged the statute on the ground, inter alia, that it effected a facial taking of Chevron's property under the Fifth and Fourteenth Amendments to the US Constitution. ${ }^{207}$ Accepting Hawaii's justification for the statute-that it was intended to prevent concentration of the retail gasoline market and resultant higher retail gasoline prices by maintaining the viability of independent lessee-dealers-both the federal district court and the Ninth Circuit Court of Appeals held that the statute would not substantially advance this interest. ${ }^{208}$ The why's and where fore's are not pertinent or relevant to this discussion. Suffice it to say that the US Supreme Court was now presented with the question of whether a regulatory measure was invalid solely for failure to advance a legitimate state interest - the first prong of the Agins test.

The Court held that it was not, that failure to advance a legitimate state interest could never be a Fifth Amendment ground for invalidating a regulatory measure. Finding that its Agins holding represented an 'apparent commingling of due process and takings inquiries [which] had some precedent' ${ }^{209}$ the Court held that 'such a

\footnotetext{
201 Ibid, at 257-258.

202 Ibid, at 262-263.

203 Lingle, 544 US at 540.

204 Ibid, at 534-535.

205 Ibid, at 533.

206 Ibid.

207 Ibid.

208 Ibid, at 534-535.

209 Ibid, at 541.
} 
test is not a valid method of discerning whether private property has been 'taken' for the purposes of the Fifth Amendment.'210 The Court so decided on several grounds.

First, it is doctrinally incorrect to concentrate on the 'effectiveness' of a regulation in advancing a governmental purpose. ${ }^{211}$ Noting that key to finding a Fifth Amendment regulatory taking is the comparability to government invasion or appropriation of private property, the Court found that the Agins test was 'tethered neither to the text of the Takings Clause nor to the basic justification for allowing regulatory actions to be challenged under the Clause,' and that therefore, ' $[t]$ he notion that such a regulation nevertheless "takes" private property for public use merely by virtue of its ineffectiveness or foolishness is untenable. 212

Second, the test presents 'serious practical difficulties' by requiring a heightened means-ends review of virtually any regulation of private property. The Court worried about the range of regulations it would then be forced to evaluate, potentially substituting its 'predictive judgments' for those of elected legislatures and expert agencies. ${ }^{213}$ Foreshadowing what the Court did in Kelo v City of New London, the Court noted that it has long eschewed such heightened scrutiny when addressing substantive due process challenges to government regulation. ${ }^{214}$

In sum, as the majority opinion implies and the concurring opinion by Justice Kennedy makes explicit, the 'substantially advances' formula has no place in the Court's Fifth Amendment takings jurisprudence. ${ }^{215}$ It is viable only as part of a Fourteenth Amendment inquiry into the arbitrary or irrational nature of a government regulation. However, as Chevron voluntarily dismissed its due process claim without prejudice, the Court had no occasion to consider a Fourteenth Amendment due process challenge to Hawaii's rent cap statute. ${ }^{216}$

\section{Relevant Parcel}

The question of relevant parcel is applicable both to total and partial regulatory takings. One of the earliest formulations of the issue in a regulatory takings context comes, again, from Penn Central: "Taking" jurisprudence does not divide a single parcel into discrete segments and attempt to determine whether rights in a particular segment have been entirely abrogated. In deciding whether a particular governmental action has effected a taking, this Court focuses rather both on the character of the action and on the nature and extent of the interference with rights

\footnotetext{
210 Ibid, at 542.

211 Ibid.

212 Ibid, at 543 .

213 Ibid, at 544.

$214 \mathrm{Ibid}$, at 544-545.

215 Ibid, at 545-549.

216 Ibid, at 549.
} 
in the parcel as a whole - here, the city tax block designated as the landmark site'. ${ }^{217}$

In 1987, the Court refused to segment property vertically, holding plaintiff coal association could not separate the mineral estate from the rest of its fee simple interests for regulatory takings purposes in Keystone Bituminous Coal Ass'n v DeBenedictis, ${ }^{218}$ cited with approval by the Court in the non-land use case of Concrete Pipe and Products of California, Inc $v$ Construction Laborers Pension Trust. ${ }^{219}$

The critical question, of course, is, what is that relevant parcel, or, as aptly phrased by the Lucas opinion: 'When, for example, a regulation requires a developer to leave $90 \%$ of a rural tract in its natural state, it is unclear whether we would analyze the situation as one in which the owner has been deprived of all economically beneficial use of the burdened portion of the tract, or as one in which the owner has suffered a mere diminution in value of the tract as a whole ... [there follows criticism of that portion of the New York state court decision in Penn Central which suggested that nearby property of the owner could be combined with that portion he claimed was unusable in deciding whether there had been a regulatory taking] ... The answer to this difficult question may lie in how the owner's reasonable expectations have been shaped by the State's law of property-ie, whether and to what degree the state's law has accorded legal recognition and protection to the particular interest in land with respect to which the takings claimant alleges a diminution in (or elimination of) value'. ${ }^{220}$

The Court has made it abundantly clear that a 3-year moratorium is not always a relevant interest in property for regulatory takings purposes in the recently-decided Tahoe-Sierra case cited in the previous section, but the Court has given no clear guidance in terms of criteria. However, several lower federal and state courts have dealt with the issue. Thus, both Florida Rock Industries, Inc $v$ United States, ${ }^{221}$ and Loveladies Harbor, Inc $v$ United States, ${ }^{222}$ discuss the denominator issue in the context of denials of section 404 (Clean Water Act) dredge and fill permits issued by the Army Corps of Engineers. In Loveladies, the court considered relevant only 12.5 of plaintiff's 250 acres, holding ultimately that the Corps effectively denied the landowner all economically beneficial use and so was liable for the difference in

217 Penn Central Transp Co v New York City, 438 US 104, 130-131 (1978).

218480 US 470 (1987).

219 Concrete Pipe and Products of California, Inc $v$ Construction Laborers Pension Trust, 508 US 602 (1993).

220 Lucas v South Carolina Coastal Council, 505 US 1003, 1016, n7 (1992).

22118 F3d 1560 (Fed Cir 1994).

22228 F3d 1171 (Fed Cir 1994). 
value with ( $\$ 2.7$ million) and without $(\$ 12,500)$ the permit. See also Palm Beach Isles Assoc v United States, 208 F3d 1374 (Fed Cir 2000).223

Moreover, in a case the outcome of which otherwise favored the City and County of Honolulu on virtually every issue argued-extent of owner's property interest to bring a takings challenge, vested rights, ripeness-the federal district court in Kaiser Development Co $v$ Honolulu, ${ }^{224}$ ended its opinion by taking a very broad view of the 'relevant parcel': 'The determination whether to treat land as a single parcel for determining its value depends on numerous factors, such as unity of use, contiguity, physical characteristics, historical considerations and how the land has been treated both by the landowner and the government. [rejecting Penn Central as distinguishable, the court continued:] Here, the primary factor supporting the single parcel theory is that Bishop owns the property as a whole. However, Queen's Beach is non-contiguous since it is separated from the rest of Hawaii Kai by a road; Queen's Beach has not been developed by Bishop as part of the residential community of Hawaii Kai; Bishop and Kaiser have always considered Queen's Beach a separate area on which they seek to build a resort. Most importantly, the City has treated Queen's Beach separately for zoning and planning purposes. The City has zoned Queen's Beach for preservation uses, while most of the rest of Hawaii Kai is zoned residential, and Queen's Beach has consistently had a different land use designation from the rest of Hawaii Kai. Under [applicable county plans] Queen's Beach has been designated either commercial resort or park/preservation while the rest of Hawaii Kai has been designated primarily for residential use. In summary, under the facts of this case, Queen's Beach is to be considered a separate parcel for the purposes of determining whether there has been a taking.225

Some courts have reached a different conclusion with respect to the relevant parcel, though many of these tend to be 'vertical' (usually surface/subsurface) parcel issues rather than the horizontal, nearby parcel cases noted above. However, in a few cases the factual context is much the same as the federal and state cases discussed in the preceding paragraph, but with different results. One such case is $K \mho \sigma K$ Construction, Inc $v$ Department of Natural Resources. ${ }^{26}$ There, the court considered all of plaintiff's adjoining parcels in holding that the denial of a permit to fill wetlands on only one of the parcels was neither a total nor a partial regulatory taking. In so holding, the court emphasized the contiguity and common ownership of the parcels, their identical zoning, and 'comprehensiveness' of the landowner's development scheme which involved all of the relevant parcels. A Michigan appeals

223 See also Palm Beach Isles Assoc v United States, 208 F3d 1374 (Fed Cir 2000); East Cape May Associates $v$ State, 693 A 2d 114 (NJ Supr Ct App Div 1997); Animas Valley Sand and Gravel Inc $v$ Board of County Comm'rs, 8 P 3d 522 (colo Ct App 2000); and Woodland Manor III Associates v Reisma, 2003 WL 1224248 (RI Super Ct 24 Feb 2003).

224649 F Supp 926 (D Haw 1986).

225 Ibid, at $947-948$ (emphasis added).

226575 NW2d 531 (Mich 1998). 
panel closely followed the reasoning in this case, holding that denial of permits to drill water wells on fourteen contiguous but separately leased or owned (by the same party) parcels would be treated as one parcel for regulatory takings analysis purposes in Oaks $v$ Montague Township. ${ }^{27}$

The Federal Court of Claims also discussed 'relevant parcel' extensively in discarding some parcels and including others (both lease and fee) for mining purposes in Appolo Fuels, Inc $v$ US. ${ }^{228}$ There, plaintiff claimed a regulatory taking after permits for mining certain of its parcels were denied. Critical factors were the timing of the acquisitions in connection with the plaintiff's overall mining plan over a five-year period. The court included some parcels acquired at different times, depending upon the way they fit into plaintiffs' mining plans and strategy, and omitted others on the same ground. The Massachusetts Supreme Court held that there was no taking where a property owner was denied permission to build a house on one of two lots that contained wetlands because the two lots were treated as a single unit and the owner sold the second lot for a substantial price, so that the land was not rendered economically valueless. ${ }^{229}$

In Coast Range Conifers v State, ${ }^{230}$ the Oregon Supreme court held that an owner's property had economically viable use, based on its entire 40 acres and not just the nine-acre parcel affected by the state's bald eagle protection regulation. The Oregon appeals court held that where logging was prohibited on 40 acres of a 200-acre

227 No 222401, 2001 WL 1512033 (Mich Ct App 27 Nov 2001). See, Banning v King County, 99 Wash App 1027 (Wash Cr App 7 Feb 2000); District Intown Properties Ltd Partnership $v$ District of Columbia, 198 F3d 874 (DC Cir 1999); Machipongo Land and Coal Company Inc $v$ Commonwealth, $799 \mathrm{~A} 2 \mathrm{~d} 751$ ( $\mathrm{Pa}$ 2002) (remanded to decide if there were nevertheless some separate parcels to be used for surface mining which was now prohibited on water pollution grounds as well as the aforementioned water-pollution-as-nuisance findings, and also setting out a series of factors relevant in deciding which is the relative parcel, citing the aforementioned Florida Rock Industries case: unity and contiguity of ownership, dates of acquisition, extent to which the proposed parcel has been treated as a single unit, extent to which the regulated lots or holdings benefit the unregulated holdings, the timing of transfers, if any, in light of the developing regulatory environment, and the owner's investmentbacked expectations and plans for development); RW Docks \& Slips v Wisconsin, 628 NW2d 781 (Wis 2001) (holding a small emergent weedbed caused by the landowner's development would be treated as part of the rest of the land owned by plaintiff in deciding whether the failure to grant a permit to construct the last phase of a marina was a regulatory taking); Daddario v Cape Cod Commission, 681 NE2d 833 (Mass 1997) (holding that an entire 70 acre parcel - rather than the 35 acres for which a sand and gravel mining permit was denied -was the relevant parcel for regulatory takings analysis in an admittedly open spacepreservation zone, because of evidence that the permitting authority would permit a less intensive mining operation than plaintiff posed, together with the suitability of the property as a whole for other developmental purposes).

22854 Fed $\mathrm{Cl} 717$ (Fed Cl 2002).

229 Giovanella $v$ Conservation Comm'n of Ashland, 857 NE2d 451 (Mass 2006).

230117 P3d 990 (Or 2005). 
parcel due to a spotted owl nesting site on adjacent land, there was no regulatory taking under the Oregon Constitution because the 200 -acre parcel, considered as a whole, retained some economically viable use since logging was still allowed there. ${ }^{231}$

Perhaps the most extensive recent relevant parcel discussion, however, comes from the Federal Court of Claims in the aforementioned Cane Tennessee case decided in June of 2003. There, recall, plaintiffs were denied certain surface mining permits (leaving them with some timbering rights, however) on several noncontiguous parcels. Noting that contiguity was only one factor in determining the 'relevant parcel' for regulatory taking analysis, the court noted that other courts had held noncontiguous parcels as one relevant parcel where the landowner 'treats legally separate parcels as a single economic unit.' Finding that plaintiff had treated all the tracts it purchased as one entity, treating them as a 'single investment for the past 24 years' it was therefore disinclined to treat them separately for purposes of a regulatory taking analysis.

\section{The 'Notice' Issue}

The notice issue goes to the question of whether what a landowner knew or should have known with respect to the relevant parcel in a regulatory takings inquiry should affect the outcome of the takings claim. With respect to a total or categorical taking, the answer is clearly no. The Lucas opinion implies as much when it compares such total taking with the exercise of eminent domain, in which knowledge of regulations affecting the relevant parcel is irrelevant. The Court in the recentlydecided Palazzolo case makes this presumption explicit. ${ }^{232}$ Although the landowner purchased property with full knowledge of a state coastal regulatory scheme that 'greatly limited' a landowner's ability to fill and develop coastal wetlands, the Court rejected the 'single sweeping rule: A purchaser or a successive title holder like petitioner is deemed to have notice of an earlier-enacted restriction and is barred from claiming that it effects a taking.' The Court held that the landowner's 'claim is not barred by the mere fact that title was acquired after the effective date of the state-imposed restriction.' To the state's claim that such a statute constituted a background principle of state law exception under Lucas, the Court directly responded: 'It suffices to say that a regulation that otherwise would be unconstitutional absent compensation is not transformed into a background principle of the state's law by mere virtue of the passage of title.'

This is also the position of the Federal Circuit in the Palm Beach Isles case decided last year and discussed briefly in the preceding section on 'denominator,' as well as the US Court of Claims in Ultimate Sportsbar v United States. ${ }^{233}$ Also a

231 Seiber $v$ State, 149 P.3d 1243 (Or Ct App 2006).

232 Palazzolo $v$ Rhode Island, 533 US 606, 625-30 (2001).

23348 Fed Cl 540, 547 (Fed Cl 2110) (citing Palm Beach Isles Assoc v United States, 231 F3d 1354,1359 (Fed Cir 2000)). 
New Jersey court so held in Rohaly $v$ State, ${ }^{234}$ in holding that a takings challenge to the placing of wells on landowner's property survived a transfer to a new landowner. Two recent decisions confirm this interpretation, both citing Palazzolo and holding that successive owners may challenge land use classifications which allegedly deny them all economically beneficial use of their relevant parcels even though they had notice of the regulatory classifications when they purchased their properties. ${ }^{235}$

However, the Palazzolo opinion contains divergent views on the application of a notice rule to partial takings. Justice O'Connor in a concurring opinion is firmly convinced that notice of an existing regulation should be part of a landowner's investment-backed expectations to be balanced against the character of the governmental action ${ }^{236}$ whereas Justice Scalia, the author of the Lucas opinion, is equally convinced it is not. ${ }^{237}$ The cases cited immediately above can be read to apply to both partial and total takings, but at least two state courts appear to agree with Justice O'Connor that notice is part of the required balancing under Penn Central in the context of partial regulatory takings challenges. ${ }^{238}$

\section{Ripeness}

Finally, a preliminary inquiry in any regulatory takings case is the extent to which the dispute is 'ripe' for a final determination. The US Supreme Court in Williamson County Regional Planning Commission v Hamilton Bank of Johnson City, ${ }^{239}$ held that plaintiff landowner's claim for compensation based on denial of subdivision

234732 A2d 524 (NJ Super Ct App Div 1999).

235 See, KCI Management, Inc v Board of Appeal of Boston, 764 NE2d 377, 380 (Mass App Ct 2002) ("We see no reason to permit challenges to the validity of a zoning enactment only by those landowners who owned land when the zoning provisions first affected it. A rule that a purchaser of real estate takes subject to all existing zoning provisions without any right to challenge any of them would threaten the free transferability of real estate, ignore the possible effect of changed circumstances, and tend to press owners to bring actions challenging any zoning provisions of doubtful validity before selling their property.'); State ex rel Shemo $v$ City of Mayfield Heights, 75 NE2d 345, 352 (Ohio 2002) ('Respondents contend that there can be no taking because the challenged single-family residential zoning existed at the time realtors acquired the property and respondents did not further restrict the preexisting residential use of the property after realtors' acquisition of it. Respondents' contention lacks merit. The United States Supreme Court recently rejected a similar argument[.]').

236 Palazzolo, 533 US at 631.

237 Ibid, at 636.

238 Fedus Associates LLC v Connecticut, 31 Conn L Rptr 463 (Conn Super Ct 2002); County Line Joint Venture $v$ City of Grand Prairie, 2001 Tex App Lexis 6000 (Tex App 31 Aug 2001). (Moreover, in Oaks, it appears that a Michigan court would continue to apply the notice rule to both varieties of regulatory takings, though whether such an interpretation would survive a federal challenge after Palazzolo is doubtful.)

239 Williamson County Regional Planning Commission v Hamilton Bank of Johnson City, 473 US 172 (1985). 
plat approval was not 'ripe' because plaintiff had not sought a variance for his proposed multi-lot project, nor had the Bank brought a claim in state court for compensation. Essentially, the Court set out a two-part test which plaintiffs seeking compensation for regulatory takings in federal courts must pass before such a court will address the merits of a takings claim:

1. the plaintiff must have received a 'final decision' from the governmental entity from which it is seeking land development permission, and

2. the plaintiff must seek and be denied compensation under state law.

The theory is that the Court cannot assess the extent of the loss or damage to plaintiff's property, particularly for partial takings purposes, until the Court has some notion of the extent of plaintiff's losses due to the challenged land use regulation. This loss arguably depends upon the finality of local or state government's application of its land use regulations and the compensation, if any, to which plaintiff may be entitled from the state. After all, it is an uncompensated taking that is unconstitutional under the Fifth Amendment, not a taking per se. The Court confirmed the application of this stringent barrier to federal court regulatory taking challenges in MacDonald, Sommer \& Frates v Yolo County, ${ }^{240}$ but noted that 'useless' and 'futile' efforts to meet the two-pronged test of ripeness were not required. The Court then applied the 'futility' exception first in the aforementioned Lucas case in 1992, and again in Suitum v Tahoe Regional Planning Agency, ${ }^{241}$ in both cases finding that it would have been futile for the plaintiff to have sought additional relief in the form of variances or special permits once the land use approving agency had denied the relevant request for land development permission, since neither were available remedies at the time the respective plaintiffs brought their original takings challenges.

Unfortunately for a landowner/developer, the burden is on the landowner to establish the inadequacy of the state compensation remedy, and neither perceived hostility nor lack of formal state processes (outside of court) to seek such compensation will save landowners from having to satisfy this prong. A leading case on this subject comes from Hawaii and was so decided by the 9th Circuit Court of Appeals in Austin v City \& County of Honolulu. ${ }^{242}$ In an earlier case decided in Hawaii, the court specifically held that where a developer had 'made only two specific applications for zone change or development at Queen's Beach [and] have made no attempt to apply for development permits, zoning changes or variances at Queen's Beach under its present zoning' it failed to meet the first prong of the

\footnotetext{
240477 US 340 (1986).

241520 US 725 (1997).

242840 F2d 678 (9th Cir 1988).
} 
ripeness test set out in the Williamson case by the US Supreme Court. ${ }^{243}$ Worse, after a landowner has pursued a state compensation remedy, res judicata and issue preclusion will often prevent a Fifth Amendment takings challenge from being maintained later in federal court under the full faith and credit provisions of 28 USC $1738 .^{244}$

In San Remo Hotel, LP $v$ City and County of San Francisco, ${ }^{245}$ the US Supreme Court refused to create an exception to the full faith and credit statute for litigants seeking to advance federal takings claims. ${ }^{246}$ While the unanimous decision is on a fairly narrow ground, it nevertheless has implications for the resolution of an increasingly common dilemma for litigants attacking land use regulations under the US Constitution's taking clauses: when required to seek relief in state court under the two-pronged ripeness requirement articulated in Williamson County Regional Planning Com'n v Hamilton Bank of Johnson City, ${ }^{247}$ the plaintiff property owner is then usually precluded from litigating the same issues in federal court. Rejecting the Second Circuit's recent opinion ${ }^{248}$ permitting such relitigation of federal taking claims in federal court by creating an exception to the federal preclusion statute, the Court first reiterated that landowner plaintiffs in takings cases have no right to pursue their federal claims in a federal forum, and second that there was no basis for an exception to the full faith and credit statute (precluding such relitigation) in takings cases, absent an express or implied statutory repeal. Finding none, the Court upheld the Ninth Circuit's denial of relief to the plaintiff landowner.

However, in a concurring opinion by Chief Justice Rehnquist, four of the nine justices suggest it is time to review the 1985 Williamson County ripeness requirement, at least with respect to the second prong which requires a litigant to seek compensation from the state before proceeding to federal court with a regulatory taking challenge to a land use regulation. However, it is generally agreed that the ripeness test (at least the first prong, and some say both prongs) applies to applied challenges of land use regulations only, and not to facial challenges.

Kaiser Development Co v Honolulu, 649 F Supp 926, 938 (D Haw 1986).

Dodd v Hood River County, 59 F3d 852 (9th Cir 1995). See, for critical comment on the insuperable barrier which Williamson County thus imposes, Thomas E Roberts, 'Ripeness and Forum Selection in Fifth Amendment Takings Litigation', $11 \mathrm{~J}$ Land Use \& Envtl L 37 (1995); Michael M Berger, 'The 'Ripeness' Mess in Federal Land Use Cases, or How the Supreme Court Converted Federal Judges into Fruit Peddlers', Inst On Planning, Zoning and Eminent Domain 7-1 (1991).

545 US 323 (2005).

246 


\section{Conclusion}

Takings jurisprudence in the United States is, by and large, a well-developed body of common law. Physical takings are measured against the backdrop of the US Constitution's Fifth Amendment at its twin requirements of public use (now public purpose) and just compensation. While there is not much left of the former under federal law, states are free to impose stricter standards under our federal system, and may have done so. The rules governing just compensation, on the other hand, are fundamentally the same either in state or federal court, and market value is the predominant factor considered in deciding how much compensation is due a landowner. The concepts appear similar to those governing in Hong Kong.

The Fifth Amendment is also clearly relevant in taking by regulation jurisprudence as well. Here, however, other (particularly common law) jurisdictions have not always accepted the rationale for treating heavily-regulated land as potentially 'taken' as if by compulsory purchase. ${ }^{249}$ Hong Kong is considering such American jurisprudence for the first time in the past few years. The relevance of total regulatory takings and its nuisance and background principles exceptions, partial takings and the investment-backed expectations and relevant parcel inquiries, all are yet to be considered. Perhaps the rich common law jurisprudence of the United States in dealing with these issues will be helpful as Hong Kong wrestles with their complexity in seeking its own resolution of takings issues. ${ }^{250}$

249 See, eg, Belfast Corp $v$ OD Cars Ltd [1960] AC 490.

250 It is also apparent from recent decisions that Hong Kong is also dealing with the question of appropriate conditions on land development (which UK courts have considered under the rubric of 'planning gain' (see David L Callies and Malcolm Grant, 'Paying for Growth and Planning Gain: An Anglo-American Comparison of Development Conditions, Impact Fees and Development Agreements', 23 Urb Law 221 (1991)) which the United States Supreme Court has exhaustively considered in Nollan $v$ California Coastal Commission, 483 US 825 (1987), and Dolan v City of Tigard, 512 US 374 (1994). This subject is discussed at length in a law review symposium article by David L Callies and Glenn H Sonoda, Providing Infrastructure for Smart Growth: Land Development Conditions, 43 Idaho L Rev 351 (2007) and is somewhat beyond the scope of this article. 
